\title{
Idaho National Laboratory Cultural Resource Monitoring Report for Fiscal Year 2007
}

\author{
Brenda R. Pace
}

October 2007

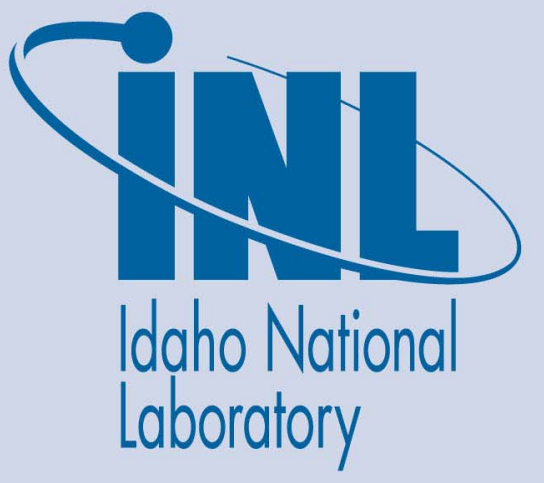

The INL is a U.S. Department of Energy National Laboratory operated by Battelle Energy Alliance 


\title{
Idaho National Laboratory Cultural Resource Monitoring Report for Fiscal Year 2007
}

\author{
Brenda R. Pace
}

October 2007

Idaho National Laboratory

Environmental Stewardship and Water Management Department Idaho Falls, Idaho 83415

Prepared for the

U.S. Department of Energy

Office of Nuclear Energy

Under DOE Idaho Operations Office

Contract DE-AC07-05ID14517 


\section{ABSTRACT}

This report describes the cultural resource monitoring activities of the Idaho National Laboratory's (INL) Cultural Resource Management (CRM) Office during fiscal year 2007 (FY 2007). In FY 2007, 40 localities were revisited: two locations of heightened Shoshone-Bannock tribal sensitivity, four caves, three butte/craters, twelve prehistoric archaeological sites, two historic stage stations, nine historic homesteads, a portion of Goodale's Cutoff of the Oregon Trail, a portion of historic trail T-16, one World War II dump, four buildings from the World War II period, and Experimental Breeder Reactor-I, a scientific facility that is designated as a National Historic Landmark and public Visitors Center. Several INL project areas were also monitored in FY 2007. This included direct observation of ground disturbing activities within the Power Burst Facility (PBF, now designated as the Critical Infrastructure Test Range Complex - CITRC), backfilling operations associated with backhoe trenches along the Big Lost River, and geophysical surveys designed to pinpoint subsurface unexploded ordnance in the vicinity of the Naval Ordnance Disposal Area. Surprise checks were also made to three ongoing INL projects to ensure compliance with INL CRM Office recommendations to avoid impacts to cultural resources. Although some impacts were documented, no significant adverse effects that would threaten the National Register eligibility of any resource were observed at any location. 


\section{CONTENTS}

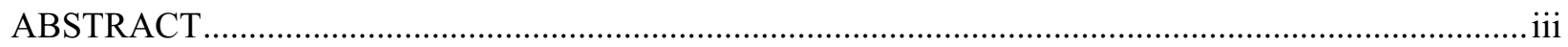

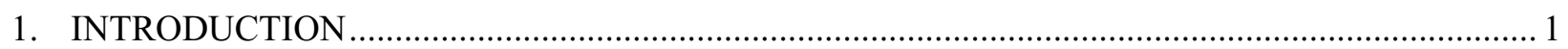

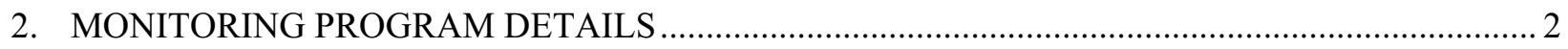

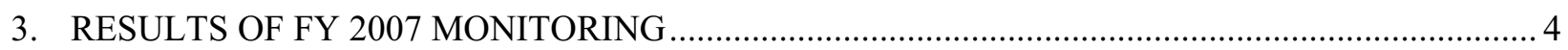

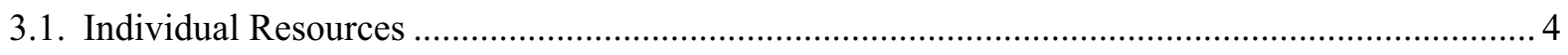

3.1.1. Resources of High Tribal Sensitivity …......................................................................... 4

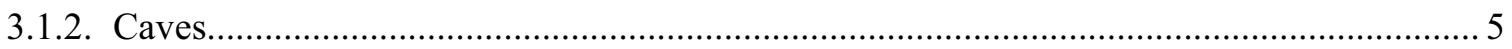

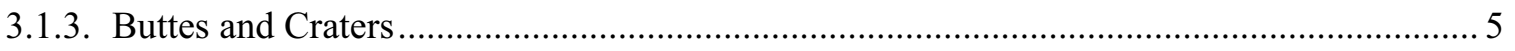

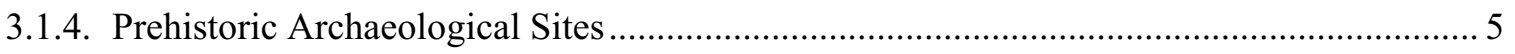

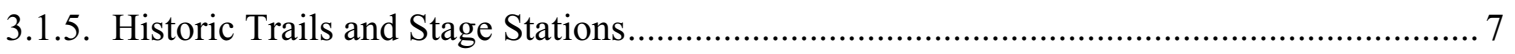

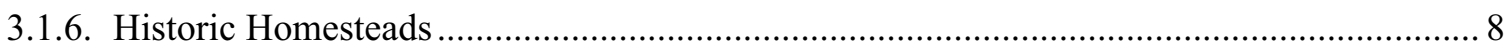

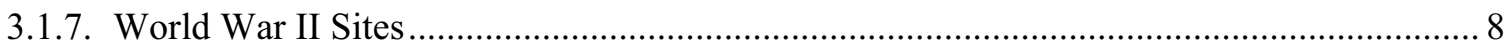

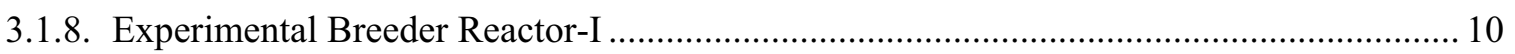

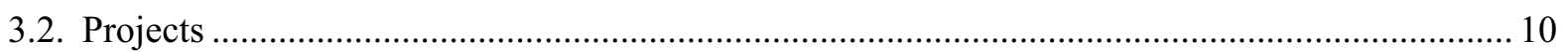

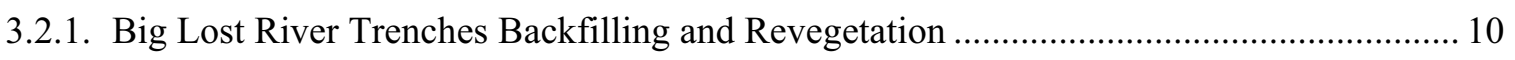

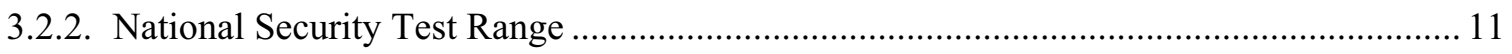

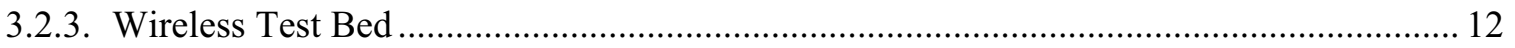

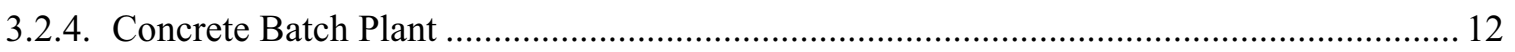

3.2.5. Geophysical Surveys for Subsurface Unexploded Ordnance ........................................... 13

3.2.6. Miscellaneous Project Activities at the Critical Infrastructure Test Range Complex/

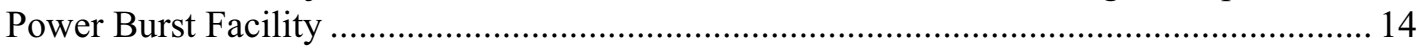

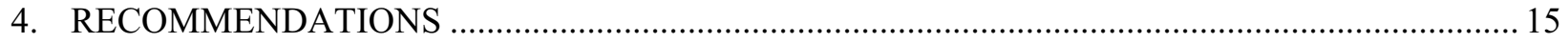

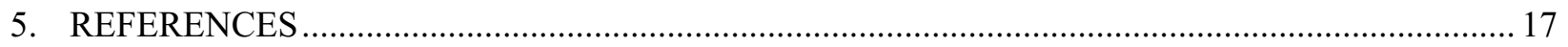




\section{FIGURES}

Figure 1: Entrance to Prickly Cave

Figure 2: Type II impacts documented at 10-JF-135 (left) and 10-JF-88 (Hellofasite, right) from powerline maintenance.

Figure 3: Animal burrowing activity at Powell Stage Station (10-BT-2194). Note orange fencing marking backhoe trench location in background....

Figure 4: Toy train located at the World War II domestic trash dump west of Central Facilities

Area

Figure 5: Peeling paint and water damage at CF-613

Figure 6: Removal of geotextile fabric from surface at site 10-BT-2189 at the location of the BLR-8 backhoe trench

Figure 7: Road maintenance and archaeological resource avoidance during upgrades to the T-25 powerline access road

Figure 8: Geophysical surveying equipment utilized at the Naval Ordnance Disposal Area. 13

Figure 9: Portion of Naval Ordnance Disposal Area after Survey with 6-Wheeler and Cart. Note slight indentations in vegetation extending away from the camera toward the distant powerline.

APPENDIX A: Field Monitoring Forms 


\section{Idaho National Laboratory Cultural Resource Monitoring Report for Fiscal Year 2007}

\section{INTRODUCTION}

The Idaho National Laboratory (INL) is an 890 square mile federal reserve covering portions of five counties on the northeastern edge of the Snake River Plain in southeastern Idaho (Irving 1993, DOEID 1996). Lands included within the boundaries of the INL are under the jurisdiction of the U.S. Department of Energy, Idaho Operations Office (DOE-ID) and have been set aside since the 1940s to support many kinds of scientific and engineering research. Currently, four main contractors perform work for DOE-ID at INL. Battelle Energy Alliance (BEA) is the primary Management and Operations contractor, $\mathrm{CH} 2 \mathrm{MHill} /$ Washington Group (CWI) takes the lead on many cleanup operations related to the Idaho Cleanup Project (ICP), Stoller Corp. conducts ecological research, and Bechtel, BWXT Idaho, LLC leads many activities for the Advanced Mixed Waste Treatment project located within the Radioactive Waste Management Complex. INL's Naval Reactor Facility is not under the jurisdiction of DOE-ID and no monitoring was conducted there in FY 2007.

Public access to INL has been restricted since its inception and an active security force patrols all lands and facilities. When encountered, trespassers are removed immediately. Largely as a result of long term access restrictions, many cultural resources on the INL are relatively undisturbed. Vandalism is also reduced due to ongoing security patrols. However, over the past decade, unauthorized access has been noted at some INL cultural resource sites, particularly those within hunting and grazing easements, or with easy access from the paved roads that bisect or are adjacent to INL boundaries. This may be related to reductions in INL Security programs (i.e. elimination of daily helicopter patrols).

Access restrictions and security patrols do not prevent all impacts and damage to cultural resources does occur. There are five primary sources of impact:

- $\quad$ Natural processes such as erosion from wind and water or animal burrowing

- $\quad$ Lack of regular maintenance or inappropriate preservation treatments for historic architectural properties

- $\quad$ Livestock grazing, herding, and associated operations (i.e. watering stations/troughs, feed transport, stock camps)

- Trespassing in highly sensitive areas and unauthorized artifact collection by members of the public and possibly INL employees unaware of penalties associated with these activities

- INL projects that go beyond the limits of their cultural resource clearances as outlined in Environmental Checklists and other documents

Under the INL Cultural Resource Management Plan (DOE-ID 2007a), BEA's INL Cultural Resource Management (CRM) Office maintains an ongoing program for monitoring, assessing, and developing strategies to mitigate impacts to cultural resources as a result of these sources of impact. This report provides a summary of the cultural resource monitoring activities completed in fiscal year 2007 (FY 2007). 


\section{MONITORING PROGRAM DETAILS}

A detailed description of the INL CRM Office monitoring program is located in Appendix L of the INL Cultural Resource Management Plan (DOE-ID 2007a). Monitoring enables INL CRM staff to document if the integrity of known resources is being compromised by natural processes, by unauthorized activities, by lack of maintenance or inappropriate preservation measures, or by INL projects. By identifying impacts to cultural resources in this manner, actions to avert further deterioration can be initiated and federal stewardship responsibilities are fulfilled.

Specific cultural resources are chosen for monitoring based on feedback from DOE-ID, the Shoshone-Bannock Tribes, and INL stakeholders. The INL CRM archives, which include documentation of over 2,200 archaeological resources and more than 200 historic architectural properties on the INL, are also consulted for appropriate candidates for yearly monitoring. Both DOE-ID and the ShoshoneBannock Tribes are often directly involved in fieldwork during the monitoring activities at these sensitive locations and other stakeholders, such as the Idaho State Historic Preservation Office (SHPO), participate occasionally. Certain resources, like Middle Butte, Prickly, and Aviators Caves, sensitive localities inside the Power Burst Facility (now Critical Infrastructure Test Range Complex-CITRC), and the Experimental Breeder Reactor-I National Historic Landmark, are monitored every year. Others, such as historic homesteads and some archaeological sites are also visited routinely because of their location in highly visible areas where trespassing has been a problem in the past. Each year INL CRM staff also conduct surveillance of resources in a wide variety of settings to address ongoing research interests.

Monitoring of INL projects is typically done under direct project funding and may be included as part of an INL Environmental Checklist or other environmental guidance. In FY 2007 monitoring was targeted at several different INL projects and involved different INL contractors. In one FY 2007 example, a Memorandum of Agreement between DOE-ID, the Idaho State Historic Preservation Office, and the Advisory Council on Historic Preservation and associated National Environmental Policy Act (NEPA) Environmental Assessment (DOE-ID 2002) mandated the surveillance and in another, monitoring was stipulated as part of a Finding of No Significant Impact associated with another NEPA Environmental Assessment (DOE-ID 2007b).

Project-specific monitoring is also routinely completed in the sandy aeolian soils inside the boundaries of the Power Burst Facility (PBF) complex (now known as the Critical Infrastructure Test Range Complex-CITRC), where Native American human remains have been discovered in both primary and secondary contexts. Cultural resource monitoring of projects that involve excavation within this facility complex is routine and required by company procedures (BEA's LWP-8000, CWI's MCP-3480). This level of cultural resource oversight ensures that any new discoveries of human remains are managed appropriately.

Forms developed by the INL CRM Office are completed for every cultural resource monitoring trip. Hard-copy and electronic versions of these documents are maintained in the INL CRM archives and are reproduced for FY 2007 here in Appendix A to this report. INL CRM archives also include a variety of photographic documentation of monitoring efforts, reproduced here only in part due to the extremely large size of these high quality electronic images.

Under the INL CRM monitoring program, there are four possible findings for a given monitoring trip, based on the level of disturbance noted:

- Type I: no visible changes to a cultural resource and/or a project is operating within the limits of cultural resource clearance recommendations 
- Type II: impacts are noted but do not threaten the National Register eligibility of a cultural resource and/or a project is operating outside of culturally cleared limitations but no cultural resources have been adversely impacted

- Type III: impacts are noted that threaten the National Register eligibility of a cultural resource and/or a project has been operating outside of culturally cleared limitations and impacts to noneligible cultural resources have occurred

- Type IV: impacts that threaten the National Register eligibility of a cultural resource are occurring during the monitoring visit, justifying the use of the INL Stop Work Authority (LWP14002, MCP-553)

If Type II, III, or IV impacts are documented during a monitoring trip, notifications are made to project managers, the DOE-ID cultural resources coordinator, and various other parties according to the severity of the disturbance and DOE-ID's discretion. Typically, Type II impacts can be corrected at once with the cooperation of INL project managers, security personnel, and/or landlord organizations. In these instances, the impacts are only reported in summary fashion in year end reports. Some Type II and all Type III or IV impacts prompt formal investigations by the INL CRM Office. INL project managers, security, and/or landlord organizations, DOE-ID, and Shoshone-Bannock tribal representatives may also participate in these investigations.

Results of all monitoring and formal impact investigations are summarized annually in a year-end report to DOE-ID (cf. DOE-ID 2006a) and also appear in a higher level summary of INL CRM Office yearly activities (cf. DOE-ID 2006b) that is sent to DOE-ID and other parties such as the Idaho State Historic Preservation Office, the Shoshone-Bannock Tribes, and stakeholders. 


\section{RESULTS OF FY 2007 MONITORING}

In all, 50 monitoring forms were completed throughout the year, including visits to 40 known resources, five projects, and three ground-disturbing activities within the PBF/CITRC (Appendix A). The DOE-ID cultural resources coordinator and tribal members from the Shoshone-Bannock Heritage Tribal Office (HeTO) participated in many of the trips and at their request, multiple trips were made to several INL Caves. The Powell Stage Station (10-BT-2194) was also revisited multiple times, largely due to the high level of activity in the vicinity associated with a large scale backfilling project. These and other monitoring results are detailed in the sections to follow. Although some impacts were documented during the year, none were determined to be adverse.

\subsection{Individual Resources}

In FY 2007, INL CRM staff conducted official surveillance of 40 individual cultural resources. As noted in the discussions to follow, a handful of resources were visited on multiple occasions. Forms that document individual observations and recommendations are included in Appendix A.

\subsubsection{Resources of High Tribal Sensitivity}

Two INL localities that include sensitive Native American human remains are visited at least once a year for monitoring and stabilization, as necessary. These are Prickly Cave (10-BT-2037) and the Waste Experimental Reduction Facility (WERF) remains (10-BT-2046). In FY 2007, no new or adverse impacts were observed at the WERF site (10-BT-2046) and measures to stabilize the sensitive remains at this locality appear to remain adequate. However, Type II impacts were documented at Prickly Cave (10BT-2037) late in the year.

Prickly Cave (10-BT-2037) is a natural lava tube brought to the attention of the INL CRM Office by security helicopter pilots in the late 1980s (Figure 1). At various times in the prehistoric past, the Cave

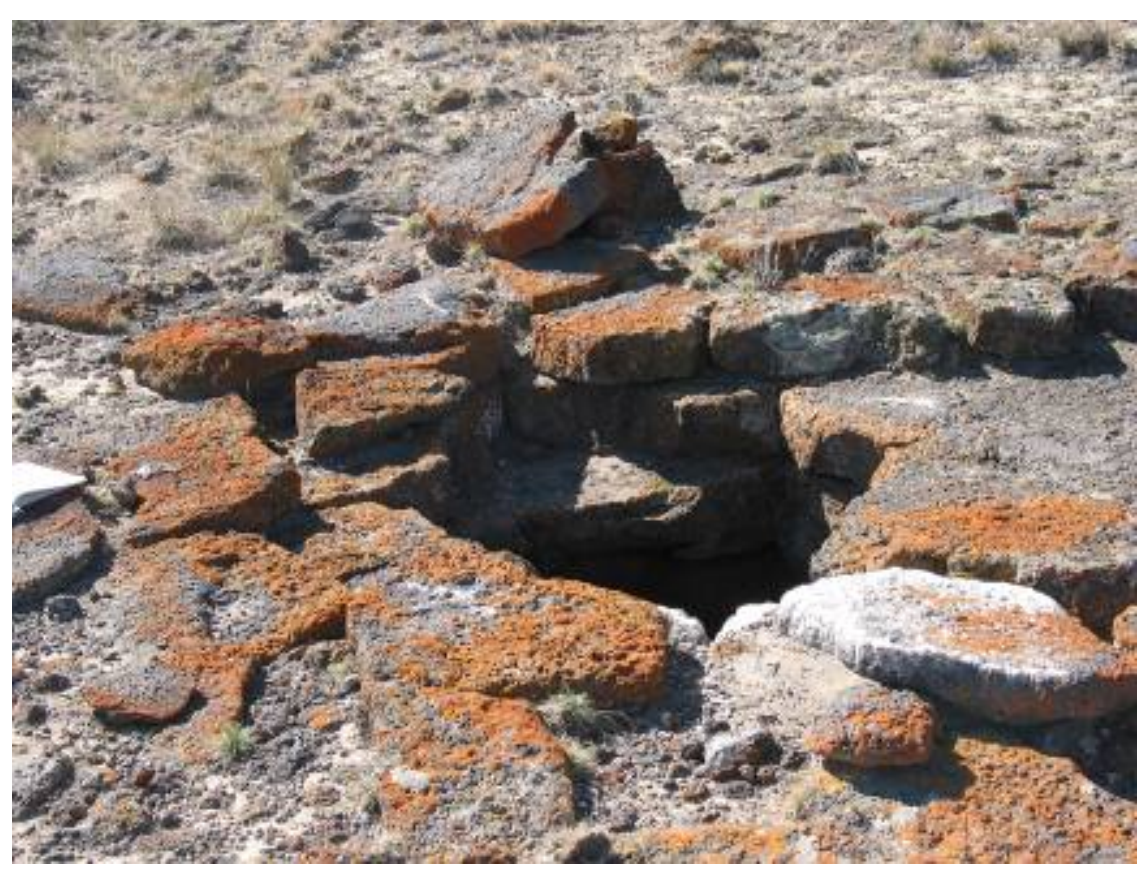

was used as a burial site for at least two Native American individuals. Human bones and perishable artifacts are located inside the lava tube and nonperishable materials occur in a scatter over the ground surface above. In the early 1990s, additional Native American human bones were salvaged from a disturbed context at the Power Burst Facility (10-BT-1991) and placed for safekeeping into Prickly Cave according to Shoshone-Bannock wishes. Since that time, yearly visits have been made to ensure that the Cave and its sensitive contents remain undisturbed.

Figure 1. Entrance to Prickly Cave. 
During the FY 2007 Prickly Cave visit, INL CRM Office staff and Shoshone-Bannock tribal representatives discovered that a human bone had been transported out of the protection of the Cave interior and deposited at ground surface. Preliminary evidence indicates that animals were the culprits in this Type II impact and that it occurred fairly recently as the bone appeared unharmed. No evidence of unauthorized human or INL project activity was observed. As of this writing the bone has been replaced in the Cave, notifications have been made to DOE-ID, and Shoshone-Bannock tribal counterparts are making necessary notifications at Fort Hall. Due to the elevated sensitivities related to this location an expanded investigation will be completed in FY 2008 to develop appropriate remediation.

\subsubsection{Caves}

All INL lava tube caves are particularly important to Shoshone-Bannock tribal members and HeTO staff. Caves also contain significant archaeological components, either inside the cave, on the surface around the cave, or both. Multiple yearly monitoring visits are often completed as a result. In FY 2007, Aviators Cave (10-BT-1582), Middle Butte Cave (10-BM-34), Moonshiners Cave (10-BM-48), and Rattlesnake Cave were monitored. At Moonshiners Cave, a range fire burned across the ground surface, removing vegetation and probably affecting surface artifacts. However, no impacts were documented during three visits there in FY 2007. Additional investigations will be completed in FY 2008. No impacts were documented during visits to the other INL Caves monitored in FY 2007 either. To aid in the future identification of unauthorized visitation at these sensitive localities, footprints created during future monitoring efforts will be lightly swept away at the completion of the official surveillance.

\subsubsection{Buttes and Craters}

INL contains many low buttes and craters with complex archaeological sites spanning thousands of years of human occupation. Rattlesnakes are also a common component at these localities and must be considered when planning field work. In FY 2007, INL CRM staff visited three of these sites, including Radio Butte (10-BM-96), Circular Butte (10-JF-95) and Cinder Butte. No new adverse impacts were documented at any of these locations.

\subsubsection{Prehistoric Archaeological Sites}

There are thousands of prehistoric archaeological sites within INL boundaries, ranging in age from more than 10,000 to 150 years old. The great antiquity of many of these sites is notable and provides justification for routine visitation and care to prevent adverse impacts. In FY 2007, INL CRM staff visited twelve prehistoric archaeological sites to assess impacts. No new impacts were documented during visits to the following localities: the Pioneer Site (10-BT-676), Juniper Bends (10-BT-675), the Borax Pit Haskett Site (10-BT-1227), the Windgap Folsom Site (10-BT-1449), and the Big Lost River Folsom site (LMIT-99-02-07). General impacts from grazing and wild animal traffic were observed at 10-JF-102 near the north end of INL, but previously recorded artifacts remained undisturbed there.

Several prehistoric archaeological sites were monitored in FY 2007 to assess impacts in relation to specific INL project activities (see Section 3.2 for additional detail on project-specific monitoring). At three prehistoric campsites located along the Big Lost River (10-BT-2192, 10-BT-2193, 10-BT-2189), no new impacts were observed as nearby backhoe trenches were backfilled. Similarly, a fourth prehistoric campsite (10-BT-1974) on the floodplain demonstrated no adverse effects associated with off-road use of a 6-wheeled All Terrain Vehicle (ATV) and cart conducting geophysical surveys to identify buried unexploded ordnance. However, this locality did exhibit disturbance from animal burrowing. At the Hellofasite (10-JF-88) and 10-JF-135, where prehistoric camps and rock structures are located, no impacts from ongoing explosive testing at the nearby National Security Test Range were apparent, but 
this must be confirmed through analysis of seismic data collected by project personnel in compliance with requirements of a NEPA Environmental Assessment (DOE 2007b).

During FY 2007 visits to archaeological sites located along Road T-25, ground disturbance associated with routine maintenance of power poles was observed. Type II impacts were documented at two archaeological sites as a result (Hellofasite-10-JF-88 and 10-JF-135) (Figure 2). Impacts consisted of heavy vehicle access and probable grading of sandy surface soils to the base area of power poles within the site areas. Consultation with BEA Facilities and Site Services and Power Management organizations indicates that this ground disturbance has been ongoing on a routine basis since installation of the power line (circa 1950). Maintenance crews report that they are careful to limit their activities to areas that have been previously disturbed. At Hellofasite (10-JF-88), impacts are lessened somewhat because gravel fill was apparently brought in during original construction of the powerline to provide a base for installation of the poles. Although heavy equipment has been taken from the existing road across the western portion of the site, most of the ground disturbance appears to have been focused in the area where the gravel fill was deposited. The rock structures at this site remain unharmed. Ongoing consultation in FY 2008 will address these activities and ensure that INL CRM staff is invited to provide feedback on future maintenance of this nature.
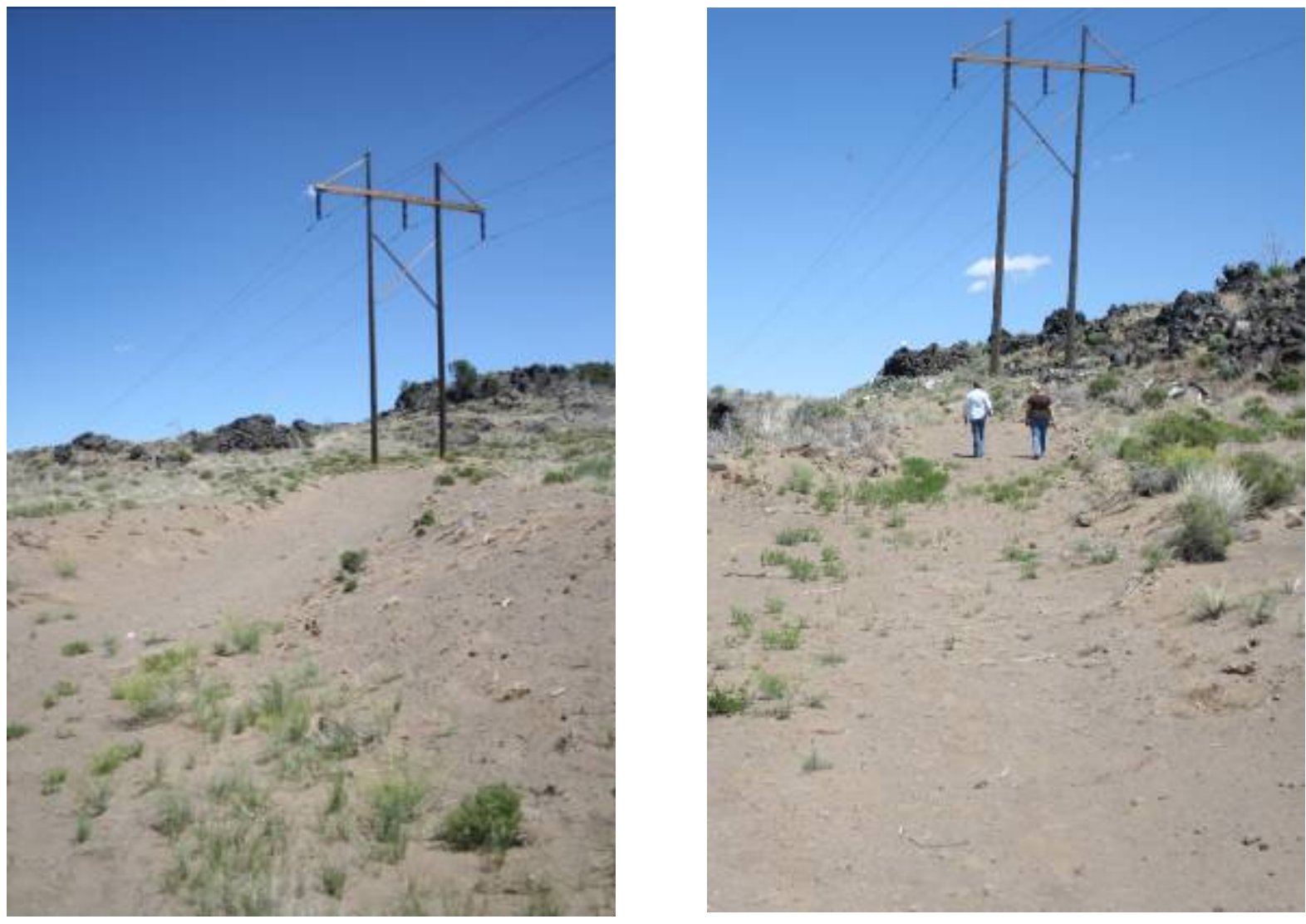

Figure 2. Type II impacts documented at 10-JF-135 (left) and 10-JF-88 (Hellofasite, right) from powerline maintenance. Note gravel fill beneath poles on the right. 


\subsubsection{Historic Trails and Stage Stations}

INL lands are crossed by a multitude of unimproved trails, many dating to historic times around the turn of the $20^{\text {th }}$ Century. These trails were important links between communities along the Snake River (e.g. Blackfoot and Eagle Rock/Idaho Falls) and those located in mountain valleys to the west and north (e.g. Mackay, Howe, Arco). People, goods, and stock passed freely along the established paths and encouraged economic growth in the region. Continued sporadic travel on the trails today by modern vehicles ensures that they remain visible on the contemporary landscape and is actually a positive impact. However, heavy vehicle traffic and inappropriate maintenance can adversely impact the trails and destroy the context of nearby archaeological resources like the remnants of stagecoach stations.

In FY 2007, adverse impacts related to inappropriate FY 2002 maintenance were still visible along one important INL trail, T-1/Goodale's Cutoff. Fortunately, undisturbed segments of this northern spur of the Oregon Trail do remain on INL lands and in places, exhibit original wear from wagon wheels. Metal scrapings, loose horse shoe nails, and broken wagon parts were also found in FY 2007 where the going was apparently rough. A second historic trail, T-16, was also investigated in FY 2007. This trail passes by many historic homesteads on the way south to the Cerro Grande townsite/railroad siding. Monitoring showed that the trail and nearby sites are in jeopardy from overuse related to modern grazing practices. INL CRM staff will work through DOE-ID to consult with the Bureau of Land Management in FY 2008 to address these impacts. Remediation might include additional survey of the road and working toward designating specific areas to locate temporary stock camps and watering stations.

Archival investigations and field surveys along historic trails have resulted in the recording of two historic stage stations on INL lands: the Powell Station and the Birch Creek Station. Both were monitored in FY 2007. One site, the Powell Station (10-BT-2194), was visited numerous times because heavy equipment was deployed within and near its boundaries during a large backfilling operation (see Section 3.2.1). The site is currently notable for its dense concentration of domestic debris, multiple basalt cobble foundations, and several basalt bridge abutments. No new impacts occurred at the stage station as a result of the backfilling project. The trail that leads to the Powell Station (T-2) also remains relatively undisturbed in spite of backhoe trenches located a short distance away. As shown in Figure 3, animal burrowing in and around structural remains at this location is causing impacts and necessitates ongoing observation and possibly intervention.

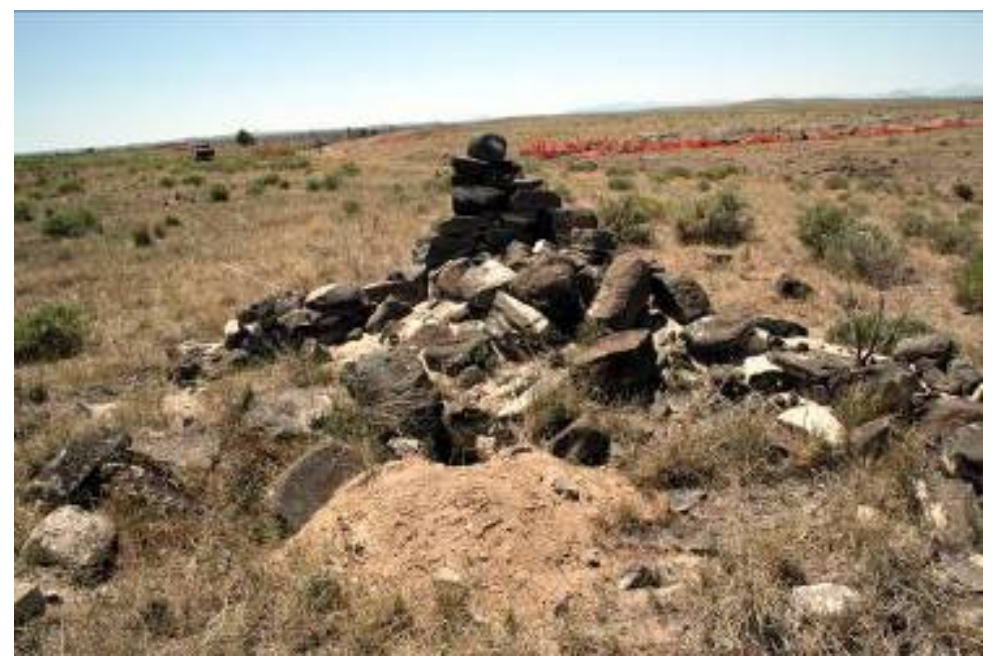

Figure 3. Animal burrowing activity at Powell Stage Station (10-BT-2194). Note orange fencing marking backhoe trench location in background. 
During FY 2007 monitoring, no new adverse impacts were observed at the Birch Creek Station located in the northern portion of the INL along the now-dry channels of Birch Creek (BEA-07-32-115). Notably, during the FY 2007 field visit to this site, INL CRM staff identified a significant artifact, an 1889 Liberty Seated dime, and noted ongoing impacts from modern grazing practices. However, the significant structural remains and surface artifacts at the site do not appear to be threatened by these activities. Although both stage stations appear to be free of impact related to INL projects, burrowing animals are at work in each location, impacting structural remains at each site (Figure 3). Continued monitoring is scheduled for these locations to determine if these impacts are becoming adverse.

\subsubsection{Historic Homesteads}

During the period from 1884 to roughly 1930, many hardy and intrepid settlers filed homestead claims on lands that would eventually be designated as the INL. U.S. federal laws that encouraged settlement of western deserts were the primary catalysts for these activities. In the INL region, the Carey Land Act of 1894 and the Desert Reclamation Act of 1902 were especially important and influential. INL CRM staff members continue to investigate archival and archaeological evidence to learn more about these activities.

In FY 2007, nine previously recorded historic archaeological sites were investigated to assess potential impacts and in some cases, to arrive at correct site type classifications (i.e. homestead, trash dump, stock camp, survey camp). Three of the sites investigated in FY 2007 (BEA-05-44-10, BEA-0544-11, BEA-05-44-12) were noted as "houses" on early 1918 survey maps of the area. After a range fire in FY 2007, artifacts and features were readily apparent at these locations and all appear to be best classified as homesteads. Although fire has probably affected individual artifacts on these sites, these impacts are not adverse. The presence of milled wood, in spite of the fire, suggests that the effects were modest.

A fourth homestead (10-BT-269) was revisited in FY 2007 to ensure that it is in no danger of impact from increased activities by CWI on the east side of the Idaho Nuclear Technology and Engineering Center facility (see Section 3.2.4). No new impacts were observed. In a fifth case, off-road ordnance surveys utilizing a 6-wheeled ATV and equipment cart under strict conditions captured in a related Environmental Checklist, were monitored through the area of a documented homestead (LMIT99-08-12) to assess the impacts associated with this kind of project activity. No artifacts were broken or displaced and structural remains were unaffected by the off-road survey, although unassociated impacts related to animal burrowing were documented. Additional information on this project is provided in Section 3.2.5.

\subsubsection{World War II Sites}

Beginning in 1942, the central portion of the INL was used by the U.S. Navy as one of only six World War II "Proving Grounds." It was the only site where the large-caliber guns and ammunition used by the Navy's Pacific Fleet were tested. Located in what is now the INL Central Facilities Area (CFA) was a Residential Area where military officers, soldiers, civilian employees and their families lived year round. A large domestic dump located a few miles west of the Residential Area provides a rare glimpse into these vintage 1940s households. Monitoring of this site (BEA-08-05-CFM-01) in FY 2007 showed no new impacts to the artifact concentration and confirmed the continued presence of several notable artifacts such as the toy train depicted in Figure 4. 


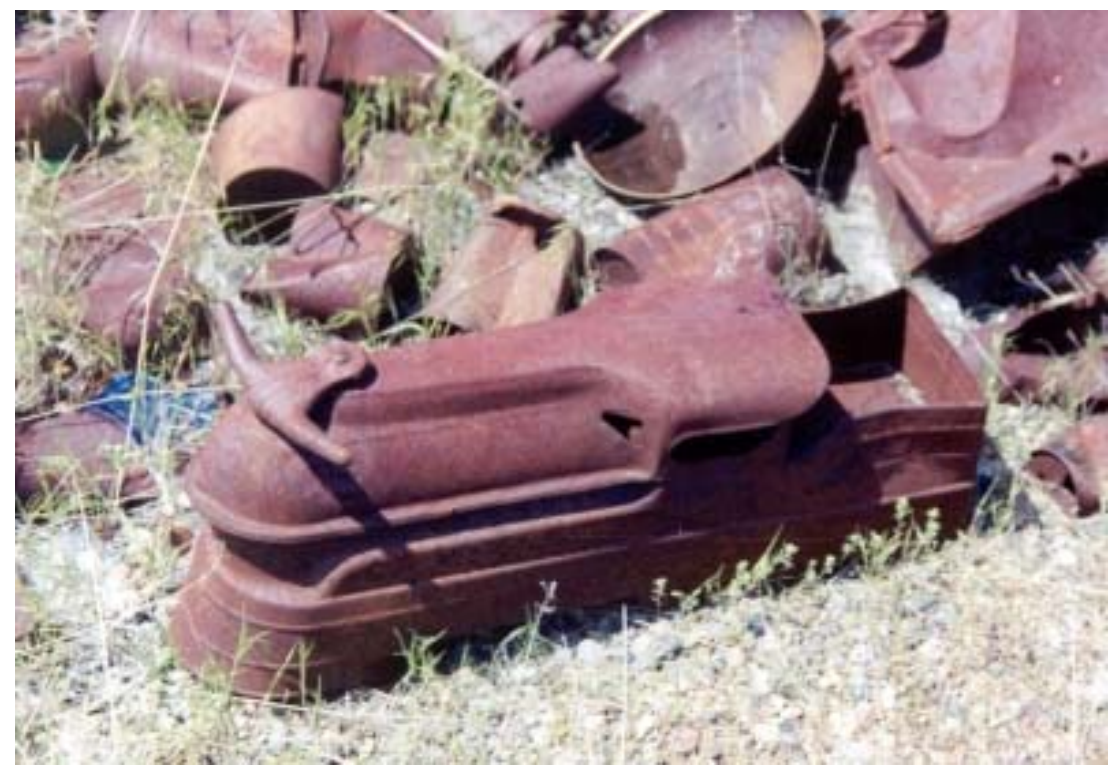

Figure 4. Toy train located at the World War II domestic trash dump west of Central Facilities Area.

In FY 2007, several brick buildings that remain from the World War II period (CF-606, CF-607, CF-613, and CF-632) were monitored. These properties are currently in inactive status. All utilities have been severed, some asbestos has been removed, and maintenance has largely been suspended as they evolve from targets for demolition to recognized features of the historic landscape. During this surveillance, Type II impacts were noted at all four buildings. The cumulative effects of minimal maintenance were obvious in the form of deteriorating porches and landscaping, interior and exterior water damage, failure of portions of interior ceilings, extensive accumulation of rodent nesting materials, cracks and breaks in windows, deteriorating and damaged water drainage systems, damage to foundations from vegetation, and spalling concrete (Figure 5). Several recommendations were made to alleviate or correct the identified impacts and were communicated via a letter report (Braun, November 17, 2006). Consultation with the BEA Facilities and Site Services organization will continue in FY 2008 toward resolution of these issues.
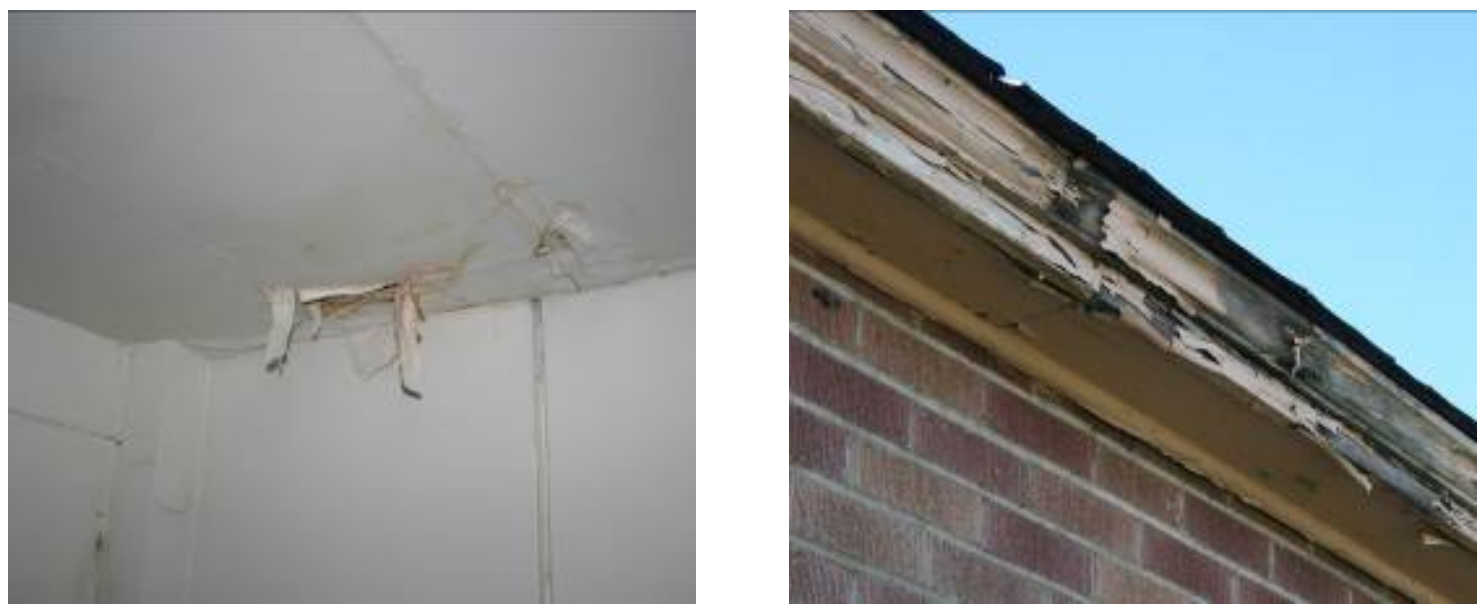

Figure 5. Water damaged interior (ceiling, left) and exterior (trim and roof, right), CF-613. 


\subsubsection{Experimental Breeder Reactor I}

Experimental Breeder Reactor-I (EBR-I) is INL's single National Historic Landmark, recognized as such because of its association with the early development of nuclear power and reactor technology. It is the only INL facility open to the public on a seasonal basis (Memorial Day through Labor Day, annually). In past years, the site has benefited from a "Save America's Treasures" grant, which supported updated exhibits to enhance the Visitors Center and addressed some preservation issues (brick and mortar restoration) (Braun 2006). In FY 2007, a lead-shielded locomotive was moved into an area just north of the EBR-I parking lot for public educational purposes. Prior to this move, a consultation letter was sent to the Idaho SHPO and an invitation to consult was sent to the National Park Service and Advisory Council on Historic Preservation as required by Programmatic Agreement. All parties concurred that no adverse impact resulted from this move to EBR-I. No other new impacts were observed from project or visitation activities at EBR-I. Efforts to address ongoing maintenance and preservation continued and recommendations were made to fix technical problems related to the educational displays and to install an adequate water drainage system.

\subsection{Projects}

Project-specific cultural resource monitoring in FY 2007 took several different forms. In one type, cultural resources recorded in the vicinity of INL projects were revisited to determine if any unanticipated impacts had occurred. In a second type, an INL CRM staff member directly observed ground disturbance associated with INL project activities. This type of monitoring occurred for projects that originally resulted in effects to cultural resources, but those effects were rendered "not adverse" through consultation and mitigation. Having a qualified archaeologist on hand to take care of any sensitive finds uncovered during ground disturbance is an accepted and widely employed tool for cultural resources mitigation in these situations. In a third type of monitoring, INL projects were randomly selected and audited for compliance with cultural resource recommendations made during the INL environmental review process. In total, six projects were monitored. Results appear in the sections to follow.

\subsubsection{Big Lost River Trenches Backfilling and Revegetation}

In 2002, DOE-ID, the Bureau of Reclamation, and various University partners initiated a paleohydrology study to develop a defensible and consistent interpretation of flood history and flood hazards on the INL. Several backhoe trenches excavated into Big Lost River floodplain deposits near the modern riverbed were necessary to support this investigation. INL CRM staff assisted this project in the assessment and mitigation of impacts to cultural resources (Pace 2002a, 2002b). A NEPA Environmental Assessment and Memorandum of Agreement between DOE-ID, the Idaho SHPO, and Advisory Council on Historic Preservation guided project activities at one trenching location (DOE-ID 2002).

In FY 2007, plans were initiated to backfill and revegetate the trenches under the direction of Stoller Corporation, DOE-ID's contractor with expertise in ecology. In compliance with the NEPA documentation and associated Memorandum of Agreement and recent recommendations from INL CRM staff and Shoshone-Bannock tribal representatives, Stoller Corporation provided support for archaeological and tribal monitoring of ground disturbance during all phases of this work.

Care was taken by project personnel during backfilling and revegetation to avoid additional impacts, particularly at trenches that were originally excavated into sensitive archaeological deposits or near sensitive historic features. At the Saddle area, this included two prehistoric archaeological sites (10BT-2192, 10-BT-2193), the Powell Stage Station (10-BT-2194), and the T-2 stage road. At the BLR-8 trench area, one large prehistoric archaeological site (10-BT-2189) was of concern. A variety of artifacts 
remain at the surface at all of the trench locations. Geotextile fabric originally placed beneath the backdirt piles at the BLR- 8 area to protect sensitive surface deposits from mixing required some time and care as the backdirt was scraped away to expose the underlying fabric. Once exposed, the fabric maintained enough strength and integrity to pull back the remaining backdirt and expose essentially undisturbed deposits beneath (Figure 6). It appears that this method worked well to protect some sensitive surface areas adjacent to the trenches. Efforts on the part of all project personnel to limit ground disturbance to previously impacted areas also helped to avoid new impacts. Cultural features like the T-2 stage road and old bridge abutments at the Powell Stage Station, located less than 20 meters from a trench, were also protected from new impacts.

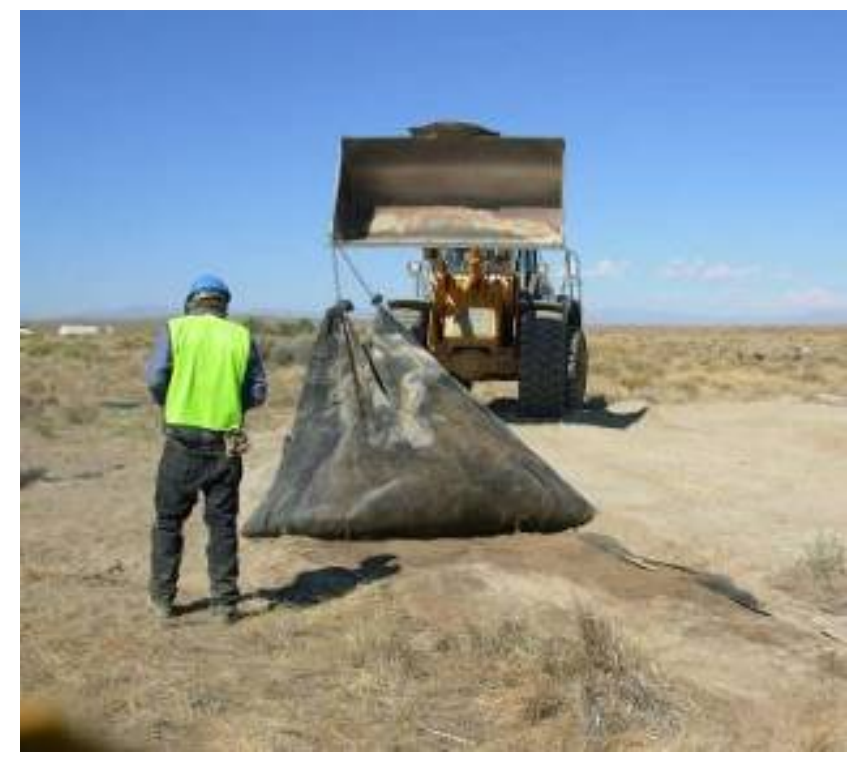

Figure 6. Removal of geotextile fabric from surface at site 10-BT-2189 at the location of the BLR-8 backhoe trench. Note undisturbed surface preserved beneath the fabric.

\subsubsection{National Security Test Range}

The Environmental Assessment completed for the National Security Test Range (DOE-ID 2007b) included minimal requirements for protection of cultural resources such as:

- $\quad$ Coordinate modifications to road T-25 (powerline road), new access road construction, and development of primary and secondary administrative areas with INL CRM to avoid blading and leveling activities inside the boundaries of identified archaeological sites

- $\quad$ Provide training in cultural resource protection for all test range personnel and escort visiting personnel to prevent accidental disturbance of cultural artifacts

- $\quad$ Monitor ground motion at nearby archaeological sites during the first three [explosive] experiments ( $>5,000 \mathrm{lb}$ explosives) and with every experiment at or exceeding $15,000 \mathrm{lb}$ explosives, unless data indicates sites are not affected

- $\quad$ Support yearly visits of known archaeological resources in the project area and take additional protective measures as necessary 
Additional recommendations were included in a survey report completed in advance of the project (Pace et al. 2006). In FY 2007, two monitoring visits were completed for this project. During the first visit, INL CRM staff worked closely with road maintenance personnel to avoid impacts to archaeological sites located along the T-25 powerline access road during blading (Figure 7). All impacts were avoided during this stage of the road maintenance work as a result of this cooperation.

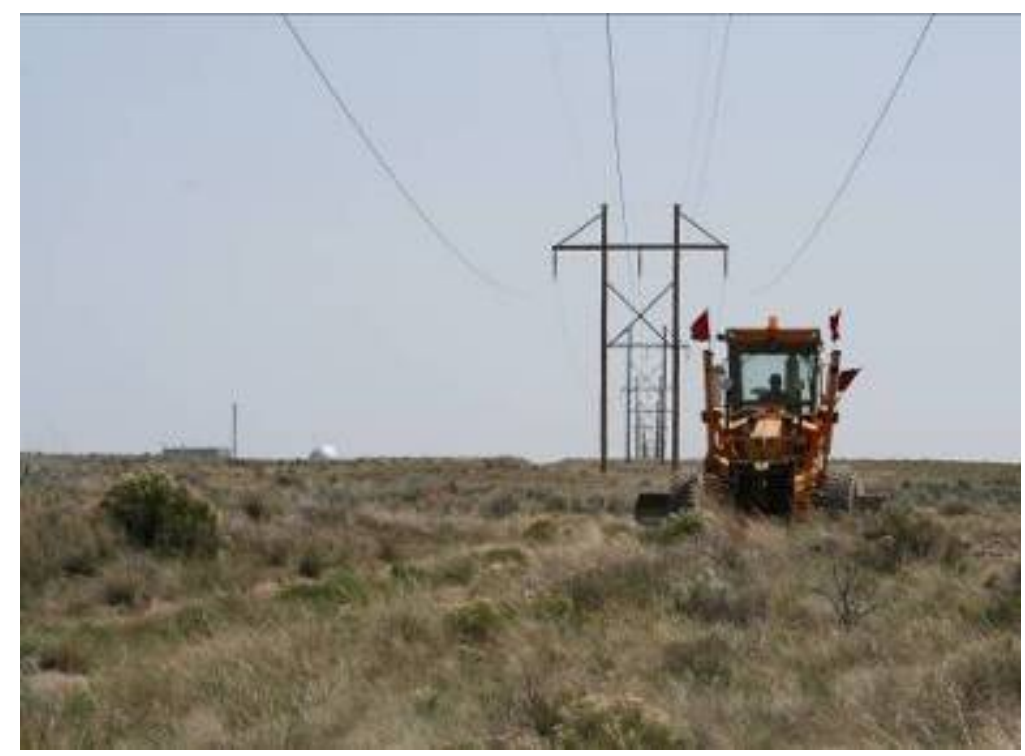

Figure 7. Road maintenance and archaeological resource avoidance during upgrades to the T-25 powerline access road.

During a second FY 2007 trip, monitoring was completed to assess ongoing overall compliance with the minimal requirements of the NEPA Environmental Assessment. At this time, several problems were observed: project activities extended into unsurveyed areas, vehicle turnarounds had been created inside the boundaries of known archaeological sites as gravel was added to road T-25, and project personnel had not been trained in cultural resource awareness and protection. Although no obvious impacts from ongoing explosive testing were observed at Hellofasite (10-JF-88), located approximately 1.3 miles from the center of the Test Range, seismic data to confirm a lack of ground motion at this sensitive location had not been provided for cultural resource consideration. BEA project personnel were contacted immediately to discuss these issues and begin the process of correcting them to prevent impacts to cultural resources. These efforts are ongoing in FY 2008 with the assistance of DOE-ID and the BEA Environmental Support organization.

\subsubsection{Wireless Test Bed}

Project developments associated with the INL Wireless Test Bed project in FY 2007 included an expansion to the Drive-By Test pads along Filmore Blvd. and addition of a new test tower associated with an existing powerline nearby. During a monitoring visit early in FY 2007, it was clear that ground disturbance was restricted to the surveyed areas and no sensitive cultural materials were being impacted by this ongoing BEA project.

\subsubsection{Concrete Batch Plant}

In FY 2007, a temporary concrete batch plant located west of the Idaho Nuclear Technology and Engineering Center was modified by CWI, DOE-ID's cleanup contractor, for permanent placement to 
support intensive ongoing and future decontamination and demolition in the area. A cultural resource monitoring visit was completed to check on compliance with cultural resource recommendations. At this time, all project activities were limited to highly disturbed areas where previous cultural resource surveys revealed no concerns. A historic homestead (10-BT-269) was also determined to be well outside the area of potential effects for the concrete plant and associated laydown areas.

\subsubsection{Geophysical Surveys for Subsurface Unexploded Ordnance}

From 1942 to 1949 and again in 1968, lands and facilities that are now part of the INL filled an important role in national defense as part of the Arco Naval Proving Ground. During these times, the U.S. Navy and Army built facilities to test-fire large naval guns used during World War II and the Vietnam War, practiced aerial bombing techniques, conducted tests to determine the most effective ways of transporting and storing ammunition and ordnance, and disposed of old ordnance devices and components that were no longer useful. One area used extensively for ordnance disposal and testing is now designated as the Naval Ordnance Disposal Area (NODA).

Cleanup of the unexploded ordnance (UXO), ordnance components, and explosive compounds that remain from these activities has been ongoing at INL since 1994. Archaeological surveys have been completed to identify archaeological resources within defined ordnance areas, including NODA, and assess the potential effects of cleanup activities on them (cf. Ringe 1994). In FY 2007, geophysical surveys were initiated to evaluate UXO that still remains beneath the surface at NODA. Magnetometers are being utilized on a 2-meter grid for this mapping.

In FY 2007, INL CRM staff included several area and project specific conditions in the project Environmental Checklist to enable the project to move forward and to reduce the potential for impacts to cultural resources. One recommendation included INL CRM staff participation in the surveys to redirect project activities if impacts to sensitive archaeological sites were occurring. Throughout FY 2007, INL CRM staff participation in the magnetometer surveys ensured that the 6-wheeled all terrain vehicle (ATV) and equipment cart used to complete the work would have no adverse effects on known historic and prehistoric archaeological sites in the NODA cleanup area. The ATV and cart are depicted in Figure 8.

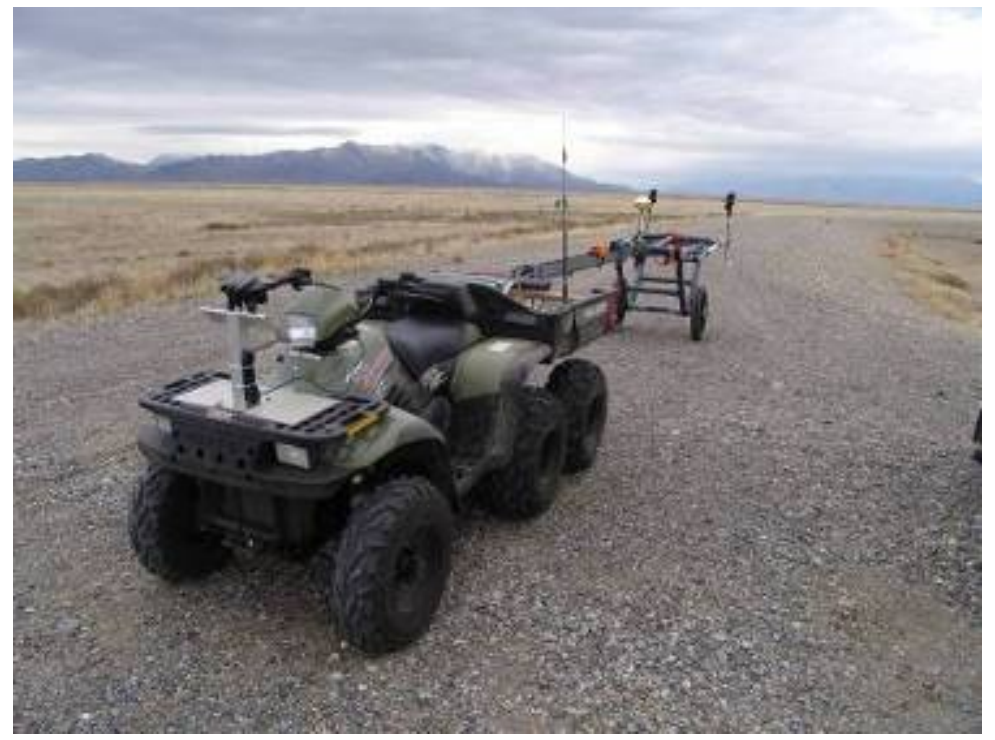

Figure 8. Geophysical surveying equipment utilized at the Naval Ordnance Disposal Area. 
In the gravelly floodplain soils common to the NODA, impacts from the ATV and cart were minimal (Figure 9). In sandier deposits, slight lateral displacement of soils was observed in the tracks of the ATV, but even these effects in these particular soils were negligible and not much greater than heavy foot traffic. At prehistoric site 10-BT-1974 and homestead LMIT-99-08-12, no adverse impacts occurred. In FY 2008, the magnetometer data collected from these localities will be analyzed for information that may aid in the study and interpretation of these archaeological sites. The ATV and cart may also be considered and evaluated for use in other ordnance cleanup areas on a case-by-case basis.

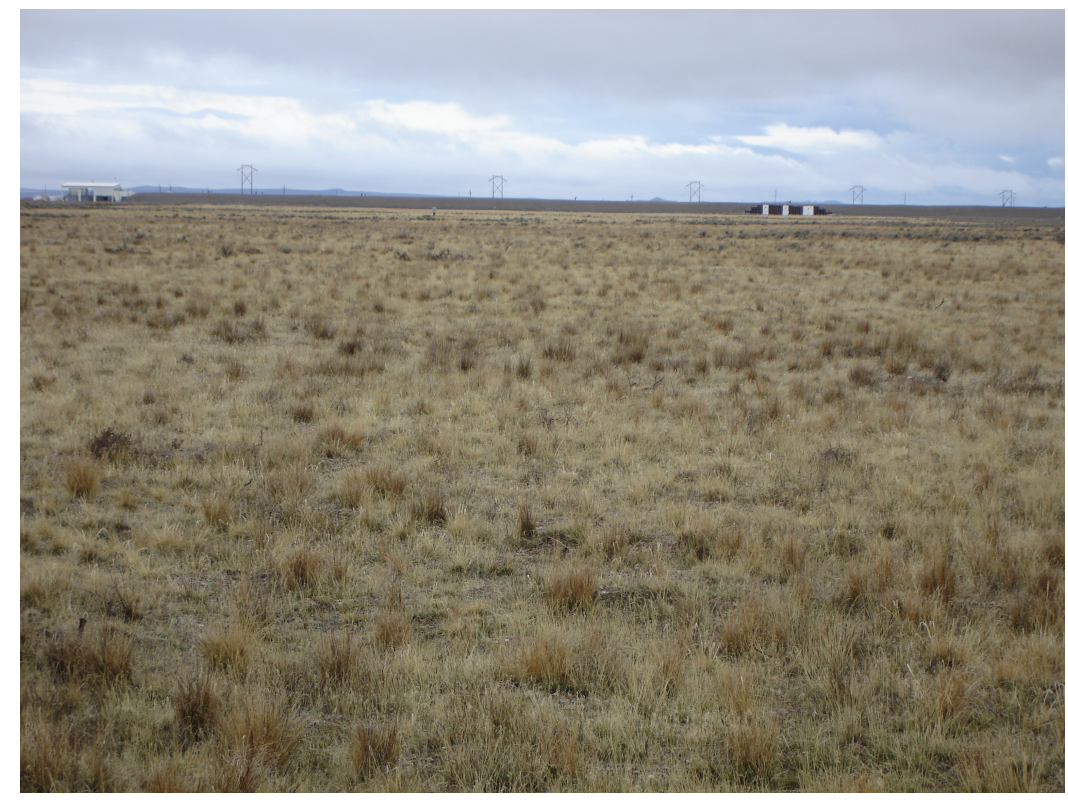

Figure 9. Portion of Naval Ordnance Disposal Area after Survey with 6-Wheeler and Cart. Note slight indentations in vegetation extending away from the camera toward the distant powerline.

\subsubsection{Miscellaneous Project Activities at the Critical Infrastructure Test Range Complex/Power Burst Facility}

Company environmental procedures require project managers to contact the INL CRM Office in advance of ground disturbance within the fenced boundary of CITRC/PBF. This is due to the occurrence of human remains in original as well as secondary contexts at two separate locations within the facility. Accelerated cleanup across the INL and new activities to support National Security have resulted in an increase in the number of projects at this facility. In FY 2007, these activities included removal of a subsurface tank, parking lot grading, and mowing. On three occasions in FY 2007, ground disturbance of this nature was monitored for human remains. No sensitive materials were observed at any time. 


\section{RECOMMENDATIONS}

Monitoring is an effective method of documenting impacts to INL cultural resources. Several broad recommendations result from FY 2007 surveillance. First, at a minimum, the condition of the following resources of high sensitivity should be assessed in FY 2008:

- $\quad$ Middle Butte Cave (10-BM-34)

- $\quad$ Aviators Cave (10-BT-1582)

- $\quad$ Pioneer Site (10-BT-676)

- $\quad$ Prickly Cave (10-BT-2037)

- WERF Remains (10-BT-2046)

- $\quad$ Powell Stage Station (10-BT-2194)

- $\quad$ Experimental Breeder Reactor I National Historic Landmark

- Goodale's Cutoff

In FY 2008, INL CRM staff should also work with DOE-ID, HeTO, and project personnel, as appropriate, to complete investigations and implement protections to prevent future impacts at Prickly Cave (10-BT-2037), EBR-I, and the World War II buildings at Central Facilities Area (CF-606, CF-607, CF-613, and CF-632). Ongoing natural impacts from burrowing animals at INL's historic stage stations (10-BT-2194, BEA-07-32-115) should also be tracked and mitigation initiated, as necessary.

In the project realm, ongoing CRM staff participation in ordnance surveys and controlled offroad use of the ATV and cart at NODA should continue. The method should also be evaluated for deployment at other ordnance areas as appropriate based on a case-by-case review. Enhanced communications must also be established with BEA Facilities and Site Services personnel to address impacts during ongoing powerline repair and maintenance. Finally, additional consultation and work with project managers is necessary to prevent impacts as a result of ongoing activities at the National Security Test Range. Here, future monitoring of the rock features and extensive surface artifacts at Hellofasite (10-JF-88) and the many archaeological sites located along the T-25 powerline road are imperative.

It is also recommended that monitoring also be conducted at several broad classes of other INL cultural resources and projects, as funding allows. At a minimum, this includes:

- $\quad$ Archaeological sites located in high traffic areas such as the INL boundary and Grazing Boundary or where unauthorized visitation is likely

- $\quad$ Historic homesteads, including those identified during ongoing archival research

- $\quad$ Historic trails

- $\quad$ Buttes, craters, and caves

- $\quad$ Late Pleistocene/Early Holocene archaeological sites 
- World War II buildings and features at Central Facilities Area and within the broader Naval Proving Ground

- $\quad$ Exhibits at EBR-I, including the aircraft engines and locomotive

- $\quad$ Experimental Breeder Reactor-II

- $\quad$ Select INL projects 


\section{REFERENCES CITED}

Braun, J. B., 2006, “Experimental Breeder Reactor I Historic Structure Report, INL/EXT-06-11909, Idaho Falls, ID.

Braun, J. B., letter report to Tom Wheeler dated 17 November 2006, INL Cultural Resource Management Office project files, Idaho Falls, ID.

DOE-ID, 1996, “Comprehensive Facility and Land Use Plan,” DOE/ID-10514, Idaho Falls, ID.

DOE-ID, 2002, Final Environmental Assessment for Geomorphic Investigations of the Big Lost River at Site BLR-8 on the INEEL, DOE/EA-1448, September 2002.

DOE-ID, 2006a, "Idaho National Laboratory Cultural Resource Monitoring Report for FY 2006," INL/EXT-06-11910, Idaho Falls, ID.

DOE-ID, 2006b, “INL Cultural Resource Management Annual Report FY 2006," INL-EXT-07-12134, Idaho Falls, ID.

DOE-ID, 2007a, "Idaho National Laboratory Cultural Resource Management Plan," DOE/ID-10997, Rev 2, Idaho Falls, ID.

DOE-ID, 2007b, "Final Environmental Assessment for the National Security Test Range," DOE/EA1557, April 2007.

Irving, J. S., editor, 1993, "Environmental Resource Document for the Idaho National Engineering Laboratory," EGG-WMO-10279, Idaho Falls, ID.

LWP-8000, BEA (INL) Laboratory-Wide Procedure, Environmental Instructions for Facilities, Processes, Materials and Equipment.

LWP-14002, BEA (INL) Laboratory-Wide Procedure, Stop Work Actions.

MCP-553, CWI (ICP) Step Back and Stop Work Authority.

MCP-3480, CWI (ICP) Management Control Procedure, Environmental Instructions for Facilities, Processes, Materials and Equipment.

Pace, Brenda Ringe, 2002a, "Site Protection Plan for the Big Loop and Saddle Geomorphic Study Areas on the Idaho National Engineering and Environmental Laboratory," INEEL/EXT-2002-494, Idaho Falls, ID.

Pace, Brenda Ringe, 2002b, "Site Protection Plan for the BLR-8 Geomorphic Study Areas on the Idaho National Engineering and Environmental Laboratory," INEEL/EXT-2002-1002, Idaho Falls, ID.

Pace, B. R., H. Gilbert, and D. Lowrey, 2006, "Cultural Resource Assessment of the National and Homeland Security Research and Development Range at the Idaho National Laboratory," INL/EXT-0611517, Idaho Falls, ID. 
Reed, W. G., J. W. Ross, B. L. Ringe, and R. N. Holmer, 1987, "Archaeological Investigations on the Idaho National Engineering Laboratory: 1984-1985, Revised Edition," Swanson/Crabtree Anthropological Research Laboratory Reports of Investigations No. 87-2, Pocatello, ID.

Ringe, B. L., 1994, "Archaeological Surveys for Ordnance Remediation at Argonne National LaboratoryWest and the Naval Ordnance Disposal Area on the INEL," EGG-CS-11319, Idaho Falls, ID. 


\section{APPENDIX A: \\ Field Monitoring Forms}

Appendix A contains electronic versions of FY 2007 monitoring forms originally completed in the field. In a few cases, when no new impacts were observed, multiple field visits to the same site location are documented on a single form. FY 2007 forms are organized according to the following categories presented in the preceding report:

- $\quad$ Resources of High Tribal Sensitivity

- $\quad$ Caves

- $\quad$ Buttes and Craters

- $\quad$ Prehistoric Archaeological Sites

- $\quad$ Historic Trails and Stage Stations

- $\quad$ Historic Homesteads

- $\quad$ World War II Sites

- $\quad$ Experimental Breeder Reactor-I

- $\quad$ Projects 


\section{A: Resources of High Tribal Sensitivity}


Monitor Number:

Monitor Name(s):

Monitor Date:

CFM-15

Clayton Marler, Carolyn Smith, JoEtta Buckhouse

9/25/07

Site Name/Number:

Prickly Cave

Reason for monitoring: Routine

Findings:

Impact Agent(s):

\section{\begin{tabular}{|l|l|}
\hline Type 1 & \\
\hline
\end{tabular}}

\section{Type 3}

Type 4

Biological; packrats, coyote, pronghorn (tracks noted just outside the cave entrance). The interior of the cave is packrat habitat and cultural materials have been scattered and jumbled extensively over the years. Fresh coyote scat was noted inside the cave and on the ledge immediately outside the cave.

Significance of Impact: $\quad$ The impact does not affect NRHP eligibility

Did disturbance or impact extend into undisturbed areas?

Yes $x$ No

If yes, describe: The human mandible from the cave interior was found ca. $10 \mathrm{~m}$ to the south of the cave entrance. The mandible appeared in excellent condition and doesn't look as if it has been outside for long.

\section{Work Halted?}

If yes, describe:

Yes

No

Notifications:

Shoshone Bannock Tribes, DOE

Primary contact(s):

Date contacted:

Willie Preacher, Julie Braun, Robert Gallegos

Julie Braun, Willie Preacher contacted 9/25/07. Robert Gallegos contacted 9/26/07

Contact Method:

E-mail
Phone $\mathrm{x}$ Official correspondence, CCN\#:

Cultural Materials observed?

$$
\text { Yes } x
$$

No $\square$

If yes, describe: Thin lithic scatter around the cave entrance. Also noted were a white quartzite knife that had been seen on past visits and a small fragmented obsidian arrow point. Although an exhaustive search was not conducted inside the cave, human bones were noted along with some of the previously discovered cultural items.

Cultural Materials collected?

Yes

No $x$

If yes, describe:

General Comments: Recommendations:

A more detailed search of the cave's interior should be undertaken (Scheduled for October). An inventory of artifacts outside of the cave should be conducted, locations mapped and a site form completed. Continue monitoring at least once per year.

Attach additional documentation, as warranted (photos, profiles, etc.)

Yes $\mathrm{X}$ No If yes, describe: Photo

Initials: $\quad$ CFM

Date: $\quad 9 / 25 / 07$ 


\begin{abstract}
Monitor Number: Monitor Name(s): Monitor Date:
\end{abstract}

BRP-06

Brenda R. Pace, Hollie Gilbert

June 15, 2007

Site Name/Number:

Reason for monitoring:

WERF Remains/10-BT-2046

Routine surveillance per requirements of DOE-ID's Native American Graves

Protection and Repatriation Act Disposition Plan and Shoshone-Bannock tribal wishes

Findings:

Impact Agent(s): $\quad$ Rodent burrows, weeds

Significance of Impact: $\quad$ Impacts are minor and have not impacted the sensitive remains.

Did disturbance or impact extend into undisturbed areas? $\quad$ Yes $\quad$ No $\quad$ No If yes, describe: Human remains continue to be stabilized beneath approximately 300 cubic yards of fill. Fence installed around the perimeter of the sensitive area continues to protect the soil berm where the human remains are located.

Work Halted?

If yes, describe:

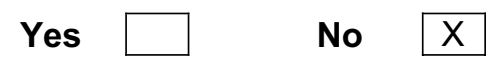

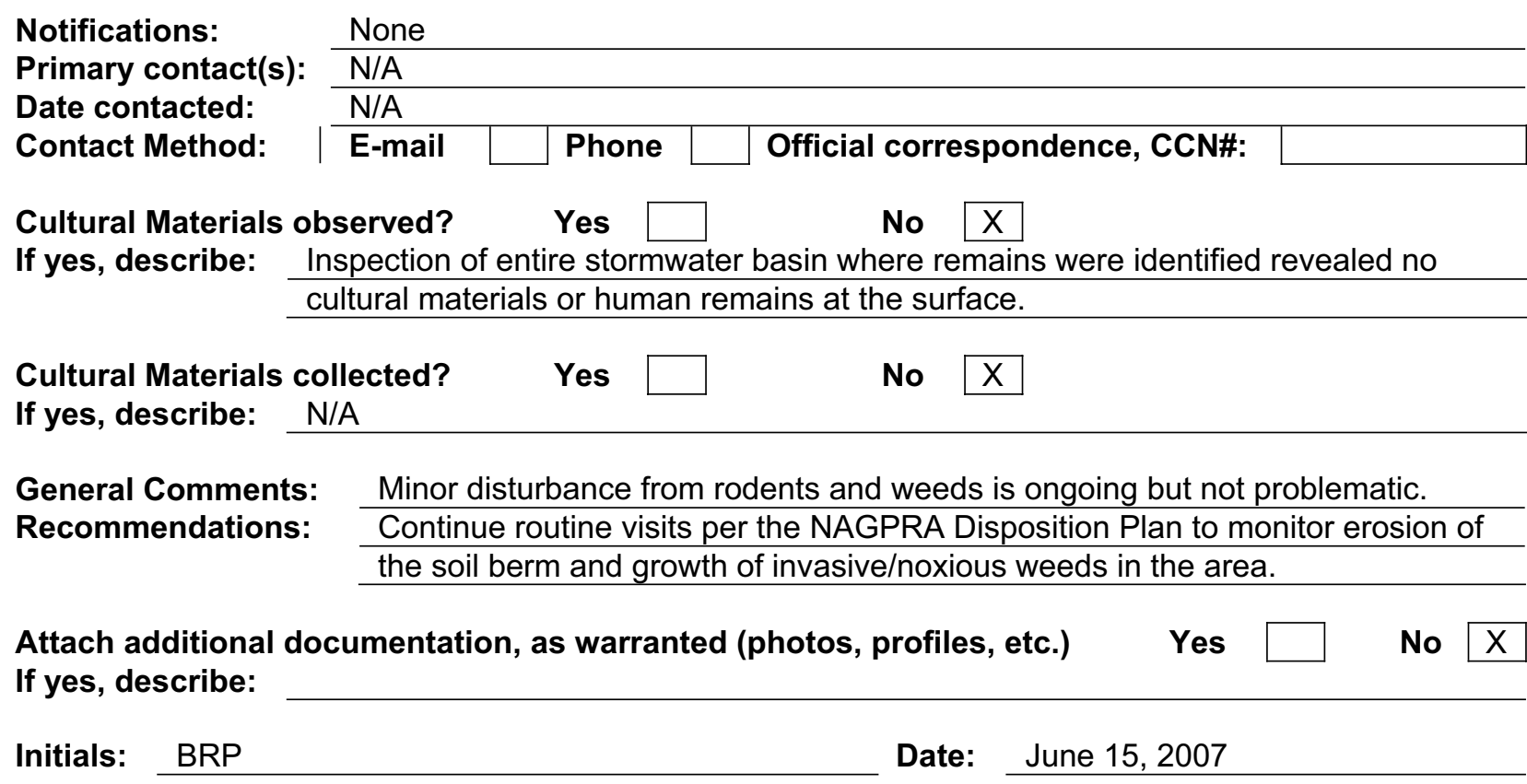




\section{Appendix A: Caves}


Monitor Number: $\quad$ CFM-06

Monitor Name(s): $\quad$ Clayton Marler, Julie Braun, Robert Gallegos, LaRae Buckskin, Carolyn Smith, Sonny Alvarez

Monitor Date: $\quad 5 / 31 / 07 ; 7 / 26 / 07$

Site Name/Number: $\quad$ 10-BT-1582

Reason for monitoring: Routine

\begin{tabular}{l|l|l|l|l|l|}
\hline Findings: & Type 1 & $\mathrm{x}$ & Type 2 & & Type 3 \\
\hline
\end{tabular}

Impact Agent(s):

Significance of Impact:

Did disturbance or impact extend into undisturbed areas?

Yes $\square$ No

If yes, describe:

Work Halted?

If yes, describe:

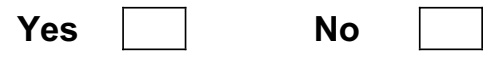

Notifications:

Primary contact(s):

Date contacted:

Contact Method: $\quad \mid$ E-mail $\quad \square$ Phone $\square$ Official correspondence, CCN\#:

Cultural Materials observed? Yes $\mathrm{x}$ No $\square$

If yes, describe: Dense lithic scatter surrounding the cave entrance

$\begin{array}{llll}\text { Cultural Materials collected? No } & \text { Yes } & \mathrm{x}\end{array}$

If yes, describe:

General Comments: This site has been impacted in the past by fire suppression activities

Recommendations: Continue monitoring at least twice per year. Sweep footprints upon exiting the cave.

Attach additional documentation, as warranted (photos, profiles, etc.) $\quad$ Yes $X$ If yes, describe: Photos

Initials: $\quad$ CFM

Date: $\quad 5 / 31 / 07 ; 7 / 26 / 07$ 
Monitor Number:

Monitor Name(s):

Monitor Date:

CFM-09

Clayton Marler, LaRae Buckskin, Carolyn Smith, Sonny Alvarez, Dino Lowrey 6/20/07; 6/27/07; 7/26/07

Site Name/Number: 10-BM-48

Reason for monitoring: Routine and post-fire check

Findings:

\begin{tabular}{|l|l|}
\hline Type 1 & $x$ \\
\hline
\end{tabular}

Type 2

Type 3

Type 4

Impact Agent(s):

Significance of Impact:

Did disturbance or impact extend into undisturbed areas?

If yes, describe:

Yes $\square$ No

Work Halted?

If yes, describe:

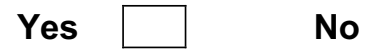

Notifications:

Primary contact(s):

Date contacted:

Contact Method:

| E-mail $\square$ Phone $\square$ Official correspondence, CCN\#:

Cultural Materials observed? Yes $x$ No

If yes, describe: Historic debris noted in and around the cave along with a sparse flake scatter and one small Elko point on the cave exterior

Cultural Materials collected? Yes $\square$ No $\mathrm{x}$

If yes, describe:

General Comments: Previous impacts to the site include vehicular traffic and 1970s fire suppression work

Recommendations: $\quad$ An updated site form should be prepared. Continue monitoring at least once per year

Attach additional documentation, as warranted (photos, profiles, etc.) $\quad$ Yes $\quad x \quad$ No If yes, describe: Photos

Initials: $\quad$ CFM

Date: $\quad 6 / 20 / 07 ; 6 / 27 / 07 ; 7 / 26 / 07$ 
Monitor Number:

Monitor Name(s):

Monitor Date:

CFM-10

Clayton Marler, LaRae Buckskin, Sonny Alvarez

6/27/07; 7/26/07

Site Name/Number: $\quad$ Rattlesnake Cave

Reason for monitoring: Routine

Findings:

\begin{tabular}{|l|l|}
\hline Type 1 & $x$ \\
\hline
\end{tabular}

Type 2

Type 3

Type 4

Impact Agent(s):

Significance of Impact:

Did disturbance or impact extend into undisturbed areas?

Yes

No

If yes, describe:

Work Halted?

Yes

No

If yes, describe:

Notifications:

Primary contact(s):

Date contacted:

Contact Method:

E-mail

Phone

Official correspondence, CCN\#:

Cultural Materials observed? Yes $\mathrm{x}$

No

If yes, describe: Thin lithic scatter

Cultural Materials collected?

Yes

No $x$

If yes, describe:

General Comments: This site has been previously impacted by a two-track road leading to the cave. Recommendations: This site should be formally recorded. Continue monitoring once per year.

Attach additional documentation, as warranted (photos, profiles, etc.) $\quad$ Yes $X$ No If yes, describe: Photo

Initials: CFM

Date: $\quad 6 / 27 / 07 ; 7 / 26 / 07$ 
Monitor Number:

Monitor Name(s):

Monitor Date:

CFM-13

Clayton Marler, LaRae Buckskin, Carolyn Smith, Sonny Alvarez $7 / 26 / 07$

Site Name/Number:

10-BM-34

Reason for monitoring: $\quad$ Post-fire check

Findings:

\begin{tabular}{|l|l|}
\hline Type 1 & $x$ \\
\hline
\end{tabular}

Type 2

Type 3

Type 4

Impact Agent(s):

Significance of Impact:

Did disturbance or impact extend into undisturbed areas?

If yes, describe:

Yes $\square$ No

Work Halted?

If yes, describe:

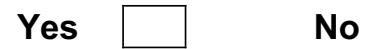

Notifications:

Primary contact(s):

Date contacted:

Contact Method:

| E-mail $\square$ Phone $\square$ Official correspondence, CCN\#:

Cultural Materials observed? Yes $x$

No

If yes, describe: Sparse flake scatter on cave exterior; pictographs inside the cave

Cultural Materials collected?

Yes

No $x$

If yes, describe:

General Comments: This site has been impacted in the past by vehicular traffic and graffiti

Recommendations: An updated site form should be prepared. Continue monitoring at least twice per year

Attach additional documentation, as warranted (photos, profiles, etc.)

Yes

No $x$ If yes, describe:

Initials: CFM

Date: $\quad 7 / 26 / 07$ 
Monitor Number:

Monitor Name(s):

Monitor Date:
BRP-17

Brenda R. Pace, Hollie Gilbert

September 7, 2007

Site Name/Number:

Reason for monitoring:

Middle Butte Cave/10-BM-34

General reconnaissance, damage assessment, and survey planning after Twin Buttes Fire.

Findings:

\begin{tabular}{|l|l|}
\hline Type 1 & $\mathrm{X}$ \\
\hline
\end{tabular}

\section{Type 2}

Type 3

Type 4

Impact Agent(s):

No new impacts noted

Significance of Impact: $\quad$ Cave was not impacted by fire or INL fire-fighting efforts

Did disturbance or impact extend into undisturbed areas?

Yes

No

If yes, describe: N/A

Work Halted?

If yes, describe:

Yes

No $\mathrm{X}$

Notifications: $\quad$ None required under Type 1 finding

Primary contact(s): N/A

Date contacted: N/A

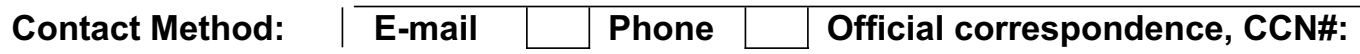

Cultural Materials observed? Yes $X$ No $\square$

If yes, describe: $\quad$ Middle Butte Cave includes a light scatter of debitage around the rim of the entrance crater and pictographs on interior walls. Numerous fire hearths are also present near the mouth of the cave but many of these are modern. Some historic and modern graffiti also occurs on interior walls. The area is of cultural importance to the Shoshone-Bannock Tribes and is the subject of a special access agreement between the Tribes and DOE-ID.

Cultural Materials collected? Yes $\square$ No $\mathrm{X}$

If yes, describe: $\mathrm{N} / \mathrm{A}$

General Comments: Cave appears to be unharmed from fire or fie-fighting efforts. Main fire break is located approximately $1 / 4$ mile to the east.

Recommendations: $\quad$ Continue routine monitoring and special monitoring in the event of a fire or other potential impacting agent.

Attach additional documentation, as warranted (photos, profiles, etc.) $\quad$ Yes $\square$ No $\quad$ X If yes, describe:

Initials: $\quad B R P$

Date: September 7, 2007 
Appendix A: Buttes and Craters 
Monitor Number:

Monitor Name(s):

Monitor Date:

CFM-02

Clayton Marler, Dino Lowrey $4 / 12 / 07$

Site Name/Number:

ISU-03-01-P28 (Cinder Butte)

Reason for monitoring: Routine

Findings:

\begin{tabular}{|l|l|}
\hline Type 1 & $\mathrm{x}$ \\
\hline
\end{tabular}

Type 2

Type 3

Type 4

Impact Agent(s):

Significance of Impact:

Did disturbance or impact extend into undisturbed areas?

If yes, describe:

Yes $\square$ No

Work Halted?

If yes, describe:

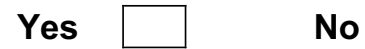

Notifications:

Primary contact(s):

Date contacted:

Contact Method:

| E-mail $\square$ Phone $\square$ Official correspondence, CCN\#:

Cultural Materials observed? Yes $\mathrm{x}$

No

If yes, describe: Extensive flake scatter, pottery, a few diagnostic projectile points

Cultural Materials collected?

Yes

No $x$

If yes, describe:

General Comments: This site has previously been impacted by two-track toads and cinder mining Recommendations: $\quad$ Continue monitoring once per year

Attach additional documentation, as warranted (photos, profiles, etc.) $\quad$ Yes $\quad X \quad$ No $\square$ If yes, describe: $\quad$ Photo

Initials: $\quad$ CFM

Date: $\quad 4 / 12 / 07$ 
Monitor Number:

Monitor Name(s):

Monitor Date:

CFM-12

Clayton Marler, Sonny Alvarez, Dino Lowrey

$7 / 19 / 07$

Site Name/Number:

10-JF-95

Reason for monitoring: Routine

Findings:

\begin{tabular}{|l|l|}
\hline Type 1 & $x$ \\
\hline
\end{tabular}

Type 2

Type 3

Type 4

Impact Agent(s):

Significance of Impact:

Did disturbance or impact extend into undisturbed areas?

If yes, describe:

Yes $\square$ No

Work Halted?

If yes, describe:

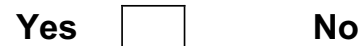

Notifications:

Primary contact(s):

Date contacted:

Contact Method:

| E-mail $\square$ Phone $\square$ Official correspondence, CCN\#:

Cultural Materials observed? Yes $\mathrm{X}$

No

If yes, describe: Medium density flake scatter, a few small pottery shards

Cultural Materials collected?

Yes

No $x$

If yes, describe:

General Comments: Two backhoe cuts (probably pre-INL) show soil depth in one and extremely rocky and limited soil depth in the other. Neither shows convincing evidence of buried cultural deposits. A two track road has impacted the site and looting is suspected.

Recommendations: $\quad$ Continue monitoring once per year.

Attach additional documentation, as warranted (photos, profiles, etc.)

Yes $\mathrm{X}$

No

If yes, describe: Photo

Initials: $\quad$ CFM

Date: $\quad 7 / 19 / 07$ 
Monitor Number:

Monitor Name(s):

Monitor Date:

CFM-14

Clayton Marler, Dino Lowrey 9/20/07

Site Name/Number: $\quad$ Telegraph Butte

Reason for monitoring: Routine

Findings:

\begin{tabular}{|l|l|}
\hline Type 1 & $x$ \\
\hline
\end{tabular}

Type 2

Type 3

Type 4

Impact Agent(s):

Significance of Impact:

Did disturbance or impact extend into undisturbed areas?

If yes, describe:

Yes $\square$ No

Work Halted?

If yes, describe:

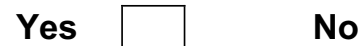

Notifications:

Primary contact(s):

Date contacted:

Contact Method:

| E-mail $\square$ Phone $\square$ Official correspondence, CCN\#:

Cultural Materials observed?

Yes $\mathrm{x}$

No

If yes, describe: Sparse flake scatter around the rim and floor of the crater.

Cultural Materials collected?

Yes

No $x$

If yes, describe:

General Comments: This site has been impacted in the past by a two-track road leading to the site and by communication tower construction. The apparent absence of formed tools and the easy access to the site from highway $20 \&$ the INL boundary suggests possible looting.

Recommendations: $\quad$ This site should be formally recorded. Continue monitoring once per year.

Attach additional documentation, as warranted (photos, profiles, etc.) Yes $\mathrm{X}$ No If yes, describe: Photo

Initials: $\quad$ CFM

Date: $\quad 9 / 20 / 07$ 


\section{Prehistoric Archaeological Sites}


Monitor Number: $\quad$ HKG-02

Monitor Name(s):

Monitor Date:

Hollie Gilbert, Julie Braun

April 19, 2007

Site Name/Number:

10-JF-102 / Ryegrass

Reason for monitoring: Routine check

Findings:

\begin{tabular}{|l|l|}
\hline Type 1 & $\mathrm{x}$ \\
\hline
\end{tabular}

\section{Type 2}

\begin{tabular}{|l|l|}
\hline Type 3 & $\mathrm{x}$ \\
\hline
\end{tabular}

Type 4

Impact Agent(s): See general comments below.

Significance of Impact:

Did disturbance or impact extend into undisturbed areas?

Yes

No $x$

If yes, describe:

Work Halted?

If yes, describe:

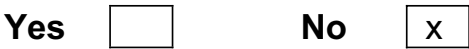

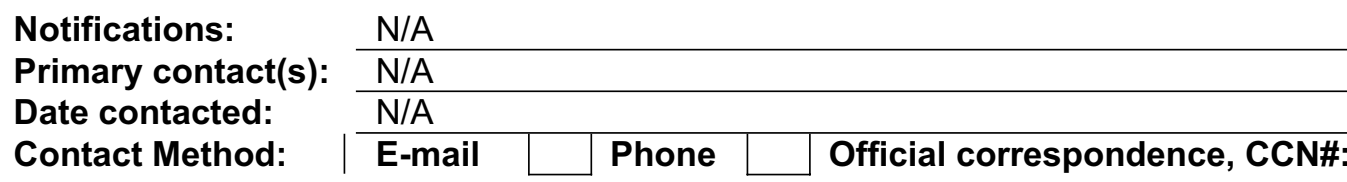

Cultural Materials observed? Yes $\mathrm{x}$ No

If yes, describe: Seam agate bi-faces previously recorded were re-located, extensive lithic scatter also noted.

Cultural Materials collected?

Yes

No $x$

If yes, describe:

General Comments:

Recommendations:

No controllable impacts were noted; however the area appears to have been heavily used recently by antelope. This site had extensive hoof prints created while the soils at the site were wet. Several new badger holes were also noted on the northwest periphery of the site. The access road into the site from State Highway 33 was overgrown with vegetation and extremely difficult to locate.

Attach additional documentation, as warranted (photos, profiles, etc.) $\quad$ Yes $\square$ No $\quad x$ If yes, describe:

Initials: $\quad H K G$

Date: April 19, 2007 
Monitor Number:

Monitor Name(s):

Monitor Date:

CFM-01

Clayton Marler, Dino Lowrey

$4 / 12 / 07$

Site Name/Number: $\quad$ 10-BT-1449

Reason for monitoring: Routine

Findings:

\begin{tabular}{|l|l|}
\hline Type 1 & $\mathrm{x}$ \\
\hline
\end{tabular}

Type 2

Type 3

Type 4

Impact Agent(s):

Significance of Impact:

Did disturbance or impact extend into undisturbed areas?

Yes

No

If yes, describe:

Work Halted?

Yes

No

If yes, describe:

Notifications:

Primary contact(s):

Date contacted:

Contact Method:

| E-mail $\square$ Phone $\square$ Official correspondence, CCN\#:

Cultural Materials observed? Yes $x$

No

If yes, describe: Medium density lithic scatter

Cultural Materials collected?

Yes

No $x$

If yes, describe:

General Comments: This site has been substantially impacted in the past by vehicular traffic, road construction/expansion, and RWMC spoils dumping

Recommendations: $\quad$ Continue monitoring once per year.

Attach additional documentation, as warranted (photos, profiles, etc.) $\quad$ Yes $\square$ No $\quad \mathrm{X}$ If yes, describe:

Initials: $\quad$ CFM

Date: $\quad 4 / 12 / 07$ 
Monitor Number:
Monitor Name(s):

Monitor Date:

CFM-03

Clayton Marler, Dino Lowrey

$4 / 12 / 07$

Site Name/Number:

10-BT-676

Reason for monitoring: Routine

Findings:

\begin{tabular}{|l|l|}
\hline Type 1 & $x$ \\
\hline
\end{tabular}

Type 2

Type 3

Type 4

Impact Agent(s):

Significance of Impact:

Did disturbance or impact extend into undisturbed areas?

If yes, describe:

Yes $\square$ No

Work Halted?

If yes, describe:

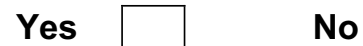

Notifications:

Primary contact(s):

Date contacted:

Contact Method:

| E-mail $\square$ Phone $\square$ Official correspondence, CCN\#:

Cultural Materials observed? Yes $x$ No

If yes, describe: Extensive flake scatter and probable eroding hearths. Buried deposits evident in stream cutbank. Foundations and dense historic debris at the Pioneer townsite.

Cultural Materials collected?

Yes

No $x$

If yes, describe:

General Comments: This site has been heavily impacted in the past through railroad construction, vehicular and pedestrian traffic, stream erosion, cattle grazing, and probable unauthorized artifact collection.

Recommendations: $\quad$ Continue monitoring at least once per year

\begin{tabular}{lll|l|} 
Attach additional documentation, as warranted (photos, profiles, etc.) & Yes & $X$ & No
\end{tabular} If yes, describe: Photo

Initials: $\quad$ CFM

Date: $\quad 4 / 12 / 07$ 
Monitor Number:

Monitor Name(s):

Monitor Date:

CFM-05

Clayton Marler, Dino Lowrey

$4 / 12 / 07$

Site Name/Number:

LMIT-99-02-07

Reason for monitoring: Routine

Findings:

\begin{tabular}{|l|l|}
\hline Type 1 & $\mathrm{x}$ \\
\hline
\end{tabular}

Type 2

Type 3

Type 4

Impact Agent(s):

Significance of Impact:

Did disturbance or impact extend into undisturbed areas?

If yes, describe:

Yes $\square$ No

Work Halted?

If yes, describe:

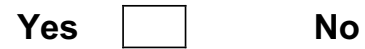

Notifications:

Primary contact(s):

Date contacted:

Contact Method:

| E-mail $\square$ Phone $\square$ Official correspondence, CCN\#:

Cultural Materials observed?

Yes $\mathrm{x}$

No

If yes, describe: Thin but extensive lithic scatter, historic irrigation ditch

Cultural Materials collected?

Yes

No $x$

If yes, describe:

General Comments: This site has been impacted in the past by two-track road traffic and historic irrigation projects.

Recommendations: $\quad$ Continue monitoring once per year

Attach additional documentation, as warranted (photos, profiles, etc.) $\quad$ Yes $\square$ No $\quad$ X If yes, describe:

Initials: $\quad$ CFM

Date: $\quad 4 / 12 / 07$ 
Monitor Number:

Monitor Name(s):

Monitor Date:

CFM-07

Clayton Marler, Robert Gallegos, Julie Braun $5 / 31 / 07$

Site Name/Number: 10-BT-675

Reason for monitoring: Routine

Findings:

\begin{tabular}{|l|l|}
\hline Type 1 & $x$ \\
\hline
\end{tabular}

Type 2

Type 3

Type 4

Impact Agent(s):

Significance of Impact:

Did disturbance or impact extend into undisturbed areas?

If yes, describe:

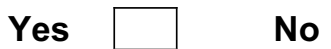

Work Halted? Yes No

If yes, describe:

Notifications:

Primary contact(s):

Date contacted:

Contact Method:

| E-mail $\square$ Phone $\square$ Official correspondence, CCN\#:

Cultural Materials observed? Yes $\mathrm{x}$

No

If yes, describe: Very dense flake scatter with several concentrations of fire-cracked rock

Cultural Materials collected?

Yes

No $x$

If yes, describe:

General Comments: This site has been impacted in the past by vehicular and pedestrian traffic and probable looting

Recommendations: $\quad$ Continue monitoring at least once per year

Attach additional documentation, as warranted (photos, profiles, etc.) Yes $\quad X \quad$ No If yes, describe: photo

Initials: CFM

Date: $\quad 5 / 31 / 07$ 
Monitor Number:

Monitor Name(s):

Monitor Date:

CFM-11

Clayton Marler, LaRae Buckskin, Sonny Alvarez $7 / 13 / 07$

Site Name/Number:

10-BT-1227

Reason for monitoring: Routine

Findings:

\begin{tabular}{|l|l|}
\hline Type 1 & $\mathrm{x}$ \\
\hline
\end{tabular}

Type 2

Type 3

Type 4

Impact Agent(s):

Significance of Impact:

Did disturbance or impact extend into undisturbed areas?

Yes

No

If yes, describe:

Work Halted?

Yes

No

If yes, describe:

Notifications:

Primary contact(s):

Date contacted:

Contact Method:

| E-mail $\square$ Phone $\square$ Official correspondence, CCN\#:

Cultural Materials observed? Yes $\mathrm{x}$

No

If yes, describe: Sparse lithic scatter

Cultural Materials collected?

Yes

No $x$

If yes, describe:

General Comments:

Recommendations:

Continue monitoring at least once per year

Attach additional documentation, as warranted (photos, profiles, etc.) $\quad$ Yes $\square$ No $\quad$ X If yes, describe:

Initials: $\quad$ CFM

Date: $\quad 7 / 13 / 07$ 


\begin{abstract}
Monitor Number: Monitor Name(s): Monitor Date:
\end{abstract}

BRP-04

Brenda R. Pace

June 6, 2007
Site Name/Number: Reason for monitoring:

10-BT-1974

Magnetometer surveys for unexploded ordnance (UXO) are utilizing a 6-Wheeler and a ightweight cart offroad to identify buried UXO and flag it for future remediation. These project activities are being monitored to determine if the offroad activity results in impacts to known historic and prehistoric archaeological sites.
Findings:
\begin{tabular}{|l|l|}
\hline Type 1 & $\mathrm{X}$ \\
\hline
\end{tabular}
Type 2
Type 3
Type 4
Impact Agent(s):
6-Wheeler/cart driving offroad, animal activity
Significance of Impact:

\begin{tabular}{l}
\hline Vehicle and cart leave shallow tracks through soft surface soils but do not \\
\hline impact harder gravel deposits. Impacts to ground surfaces appear to be \\
\hline minimal, not much greater than intensive pedestrian activity. All surface \\
\hline deposits in this area are heavily impacted by gophers, ground squirrels, and \\
\hline badgers.
\end{tabular}

Did disturbance or impact extend into undisturbed areas?

Yes $\mathrm{X}$

No

If yes, describe: At the present time, 6-Wheeler/cart surveys are restricted to areas previously surveyed for archaeological resources to assess impact and suitability for limited future deployment in unsurveyed areas. These areas are largely undisturbed.

Work Halted?

If yes, describe:

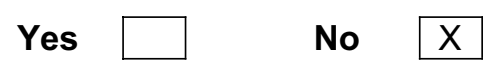

Notifications:

Primary contact(s): N/A

Date contacted:

Contact Method:

N/A
$\frac{\frac{N}{N / A}}{N / A}$
$\frac{N-m a i l}{\text { N-me }}$

Yes

No

Cultural Materials observed? Yes $\mathrm{X}$

Official correspondence, CCN\#:

If yes, describe: Dispersed scatter of obsidian flakes. No diagnostic materials observed at this time.

Cultural Materials collected? Yes $\square$ No $\quad$ N
If yes, describe: N/A

General Comments: $\quad$ On the floodplain deposits around NODA, offroad use of the 6-Wheeler and cart does not appear to adversely impact historic or prehistoric archaeological sites.

Faint tracks are visible through softer soils, but not on flood gravels. No surface artifacts were displaced or broken. Impacts are comparable to intensive foot traffic.

Recommendations: Conduct additional monitoring if subsurface ordnance are flagged for cleanup/ remediation inside the boundaries of this site.

Attach additional documentation, as warranted (photos, profiles, etc.)

Yes $\mathrm{X}$

No If yes, describe: photographs

Initials: $\quad$ BRP

Date: June 6, 2007 


\begin{abstract}
Monitor Number: Monitor Name(s): Monitor Date:
\end{abstract}

BRP-08

Brenda R. Pace, Hollie Gilbert, Julie Braun

June 18, 2007
Site Name/Number: Reason for monitoring:

Hellofasite/10-JF-88

Routine surveillance of archaeological sites in vicinity of Large Scale Explosive Test Range

\section{Findings:

\begin{tabular}{|l|l|}
\hline Type 1 & \\
\hline
\end{tabular}

\begin{tabular}{|l|l|}
\hline Type 2 & $\mathrm{X}$ \\
\hline
\end{tabular}

\begin{tabular}{|l|l|}
\hline Type 3 & \\
\hline
\end{tabular} \\ Type 4 \\ Impact Agent(s): $\quad$ Power pole inspection, maintenance, and repair. No obvious impacts \\ Significance of Impact: \begin{tabular}{l} 
associated with the Large Scale Explosive Test Range. \\
\cline { 2 - 2 } Heavy equipment has caused soil disturbance around power poles.
\end{tabular} \\ Did disturbance or impact extend into undisturbed areas?

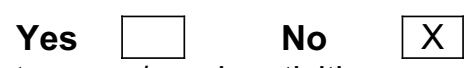 \\ If yes, describe: Disturbed areas have been impacted by previous maintenance/repair activities. Disturbance did not extend outside these previously impacted zones.}

Work Halted?

If yes, describe:
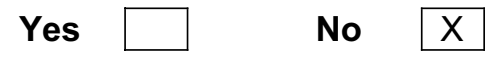

Notifications:

No ongoing work.

\section{Environmental Compliance}

Primary contact(s): Ken Tuck, John Weathersby, Tim Griffith, John Irving, Bob Montgomery

Date contacted:

Contact Method: June 19, 2007, September 26, 2007

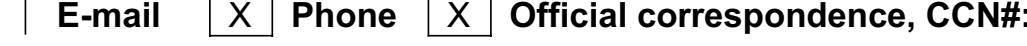

$\begin{array}{ll}\text { Cultural Materials observed? Yes } & \text { Y No } \\ \text { If yes, describe: } & \text { In } 1984 \text { the site was named "Hellofasite" for the dense, diverse scatter of artifacts }\end{array}$

If yes, describe: $\quad$ In 1984 the site was named "Hellofasite" for the dense, diverse scatter of artifacts

firmed. In 2007, flakes were observed around a gravel pad and in sandy soils surrounding a power pole in the western end of the site. Remainder and majority of site to the east remains apparently undisturbed.

Cultural Materials collected? Yes $\square$ No $\mathrm{X}$ If yes, describe: $\mathrm{N} / \mathrm{A}$

General Comments: Visual inspection of site and rock walls indicates no impact resulting from explosive testing but this is not confirmed by seismic data. Power line repair has cause extensive soil disturbance but appears to be restricted to areas previously impacted adjacent to the poles. Test Range personnel commented on disturbance by power line crew, suggesting that they should be relieved of their monitoring responsibilities because of the ground disturbance.

Recommendations: $\quad$ Continue monitoring. Determine if seismic data were collected during recent explosive tests and analyze for measurable ground motion. Work closely with Power Management to prevent additional impact and coordinate cultural resource monitoring of future work here and in other sensitive areas. Obtain support for archaeological awareness training for Test Range personnel.

Attach additional documentation, as warranted (photos, profiles, etc.) $\quad$ Yes $\square$ No $\quad \mathrm{X}$ If yes, describe:

Initials: $\quad$ BRP Date: June 18, 2007 
Monitor Number:
Monitor Name(s):
Monitor Date:

BRP-09

Brenda R. Pace, Hollie Gilbert, Julie Braun

June 18, 2007

Site Name/Number:

Reason for monitoring:

10-JF-135

Routine surveillance of archaeological sites in vicinity of Large Scale Explosive Test Range

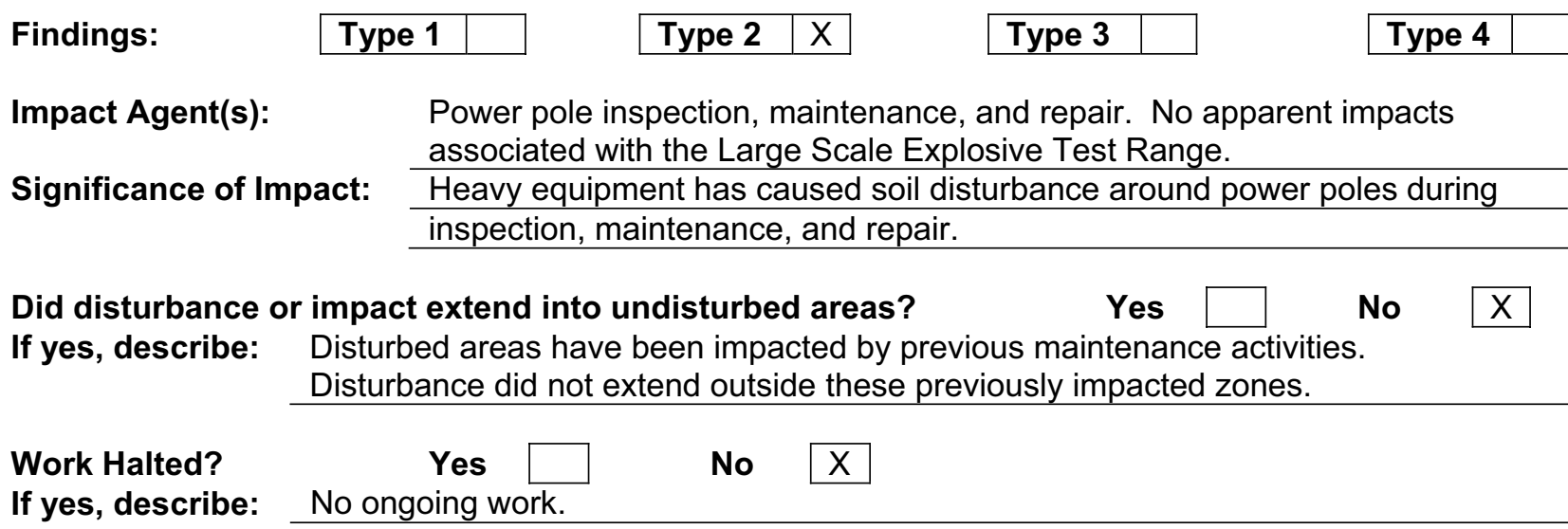

Notifications: $\quad$ BEA Facilities and Site Services

Primary contact(s): Ken Tuck,

Date contacted: June 19, 2007

Contact Method: $\quad \mid$\begin{tabular}{l|l|l|l|l} 
E-mail & & Phone & $X$ & Official correspondence, CCN\#:
\end{tabular}

Cultural Materials observed? Yes $X$ No $\square$

If yes, describe: $\quad$ In 1984 a dense, diverse scatter of artifacts was documented in this location. In 2007, artifacts were observed in disturbed soils around the base of a power pole. Majority of site to the east appears to remain undisturbed.

Cultural Materials collected? Yes $\square$ No $\mathrm{X}$ If yes, describe: N/A

General Comments: Visual inspection of site indicates no impact resulting from explosive testing. Power line repair has cause extensive soil disturbance but appears to be restricted to areas previously used during power line maintenance and repair adjacent to the poles.

Recommendations: $\quad$ Continue monitoring at this sensitive location. Work closely with Power Management to prevent additional impact and coordinate cultural resource monitoring of future work here and in other sensitive areas.

Attach additional documentation, as warranted (photos, profiles, etc.) $\quad$ Yes $\square$ No $\quad$ N If yes, describe:

Initials: $\quad$ BRP

Date: June 18, 2007 


\begin{abstract}
Monitor Number: Monitor Name(s): Monitor Date:
\end{abstract}

BRP-13

Brenda R. Pace

October 17, 2006 - September 6, 2007

Site Name/Number:

10-BT-2189/BLR-8 Trenches

Reason for monitoring:

Project compliance with Memorandum of Agreement and consultation with the Shoshone-Bannock Tribes

Findings:

\begin{tabular}{|l|l|}
\hline Type 1 & $\mathrm{X}$ \\
\hline
\end{tabular}

Type 2

Type 3

Type 4

Impact Agent(s):

Heavy equipment

Significance of Impact: $\quad$ No impacts beyond original disturbed area

Did disturbance or impact extend into undisturbed areas?

Yes $\square$ No $\mathrm{X}$

If yes, describe: Backfilling operations carefully designed to prevent disturbance outside the original area of potential effect.

Work Halted?

If yes, describe:

Yes

No

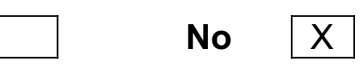

Notifications:

Primary contact(s):

Date contacted:

Contact Method:

$\mathrm{N} / \mathrm{A}$

\section{$\begin{array}{llll}\text { Cultural Materials observed? } & \text { Yes } & \mathrm{X} & \text { No }\end{array}$}

If yes, describe: Trenches were originally placed inside the boundaries of this prehistoric campsite. Artifacts and cultural features occur throughout the area and were observed during the backfilling operations in undisturbed areas around the trenches.

\section{Cultural Materials collected? Yes $\square$ No $\mathrm{X}$}

If yes, describe: N/A

General Comments: $\quad$ Backfilling activities began on August 28 and finished on September 6, 2007. Heritage Tribal Office monitors were present each day. Project personnel were cooperative and concerned about cultural resource protection, minimizing impact as much as possible. Strong geofabric placed beneath the backdirt piles at this location worked well in providing some protection to the surface and sensitive artifacts located there. No new impacts occurred and no new artifacts were observed in the backdirt.

Recommendations: $\quad$ Monitor revegetation efforts in October.

Attach additional documentation, as warranted (photos, profiles, etc.) Yes $\quad X \quad$ No $\square$ If yes, describe: photographs

Initials: $\quad B R P$

$$
\text { BRP }
$$

Date: $\quad$ August $28-30,2007$

September 4 - 6, 2007 


\begin{abstract}
Monitor Number: Monitor Name(s): Monitor Date:
\end{abstract}

BRP-14

Brenda R. Pace

October 17, 2006 - September 6, 2007

Site Name/Number: 10-BT-2194/Long Saddle Trench Reason for monitoring: Project compliance with Memorandum of Agreement and consultation with the Shoshone-Bannock Tribes

Findings:

\begin{tabular}{|l|l|}
\hline Type 1 & $\mathrm{X}$ \\
\hline
\end{tabular}

Type 2

Type 3

Type 4

Impact Agent(s):

Heavy equipment

Significance of Impact: $\quad$ No impacts beyond original disturbed area

Did disturbance or impact extend into undisturbed areas?

Yes

No $\mathrm{X}$

If yes, describe: Backfilling operations carefully designed to prevent disturbance outside the original area of potential effect.

Work Halted?

If yes, describe:

Yes

No

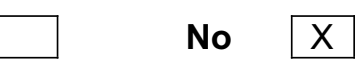

Notifications:

Primary contact(s):

Date contacted:

Contact Method:

$\mathrm{N} / \mathrm{A}$

\section{$\begin{array}{llll}\text { Cultural Materials observed? } & \text { Yes } \mathrm{X} \text { No }\end{array}$}

If yes, describe: $\quad$ Trenches were originally placed inside the boundaries of this historic stage station. Artifacts and cultural features occur throughout the area and were observed during the backfilling operations in undisturbed areas around the trenches.

\section{$\begin{array}{llll}\text { Cultural Materials collected? } & \text { Yes } & \end{array} \quad \mathrm{X}$}

If yes, describe: N/A

General Comments: $\quad$ Backfilling activities began on August 28 and finished on September 6, 2007. Heritage Tribal Office monitors were present each day. Project personnel were cooperative and concerned about cultural resource protection, minimizing impact as much as possible. No new impacts occurred and no artifacts were observed in the backdirt.

Recommendations: $\quad$ Monitor revegetation efforts in October.

Attach additional documentation, as warranted (photos, profiles, etc.) Yes $\mathrm{X}$ No If yes, describe: photographs

Initials: $\quad B R P$ BRP
Date:

August 28 - 30, 2007

September 4 - 6, 2007 


\begin{abstract}
Monitor Number: Monitor Name(s): Monitor Date:
\end{abstract}

BRP-15

Brenda R. Pace

October 17, 2006 - September 6, 2007

Site Name/Number: 10-BT-2192/Short Saddle Trench Reason for monitoring: Project compliance with Memorandum of Agreement and consultation with the Shoshone-Bannock Tribes

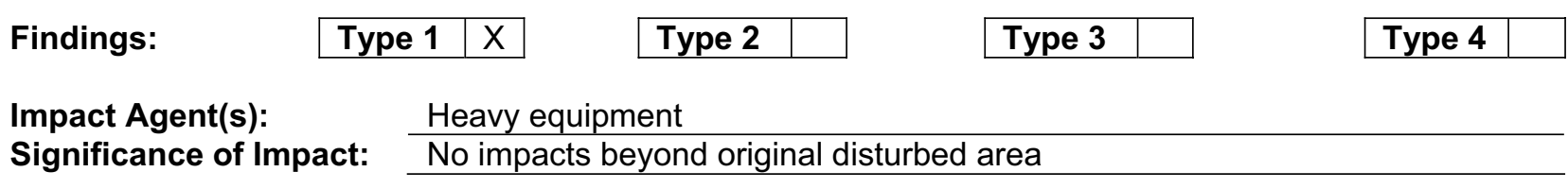

Did disturbance or impact extend into undisturbed areas? Yes $\square$ No $\mathrm{X}$

If yes, describe: Backfilling operations carefully designed to prevent disturbance outside the original area of potential effect.

\begin{tabular}{llll} 
Work Halted? & Yes \\
If yes, describe: & N/A & No $\quad X$ \\
\hline
\end{tabular}

Notifications: Shoshone-Bannock Tribes

Primary contact(s): Caroline Smith

Date contacted: $\quad$ Multiple communications

\begin{tabular}{l|l|l|l|l|l|} 
Contact Method: & E-mail & $\mathrm{X}$ & Phone & $\mathrm{X}$ & Official correspondence, CCN\#:
\end{tabular}

Cultural Materials observed? Yes $\mathrm{X}$ No

If yes, describe: Trenches were originally placed inside the boundaries of this prehistoric lithic scatter. Artifacts and cultural features occur throughout the area and were observed during the backfilling operations in undisturbed areas around the trenches.

Cultural Materials collected? Yes $\square$ No $\mathrm{X}$

If yes, describe: $\mathrm{N} / \mathrm{A}$

General Comments: $\quad$ Backfilling activities began on August 28 and finished on September 6, 2007. Heritage Tribal Office monitors were present each day. Project personnel were cooperative and concerned about cultural resource protection, minimizing impact as much as possible. No new impacts occurred and no artifacts were observed in the backdirt.

Recommendations: $\quad$ Monitor revegetation efforts in October.

Attach additional documentation, as warranted (photos, profiles, etc.) $\quad$ Yes $X$ No $\quad$ N If yes, describe: photographs

Initials: $\quad B R P$ BRP
Date:

August $28-30,2007$

September 4 - 6, 2007 


\begin{abstract}
Monitor Number: Monitor Name(s): Monitor Date:
\end{abstract}

BRP-16

Brenda R. Pace

October 17, 2006 - September 6, 2007

Site Name/Number: 10-BT-2193/Short Saddle Trench Reason for monitoring: Project compliance with Memorandum of Agreement and consultation with the Shoshone-Bannock Tribes

Findings:

\begin{tabular}{|l|l|}
\hline Type 1 & $\mathrm{X}$ \\
\hline
\end{tabular}

Type 2

Type 3

Type 4

Impact Agent(s):

Heavy equipment

Significance of Impact: $\quad$ No impacts beyond original disturbed area

Did disturbance or impact extend into undisturbed areas?

Yes

No $\mathrm{X}$

If yes, describe: Backfilling operations carefully designed to prevent disturbance outside the original area of potential effect.

Work Halted?

If yes, describe:

Yes

No

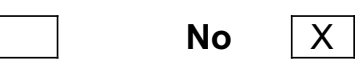

Notifications:

Primary contact(s):

Date contacted:

Contact Method:

$\mathrm{N} / \mathrm{A}$

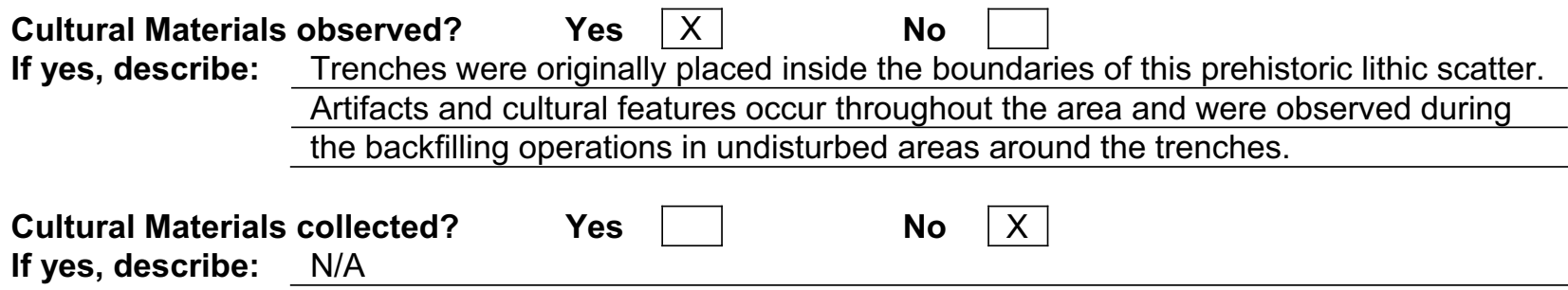

General Comments: $\quad$ Backfilling activities began on August 28 and finished on September 6, 2007. Heritage Tribal Office monitors were present each day. Project personnel were cooperative and concerned about cultural resource protection, minimizing impact as much as possible. No new impacts occurred and no artifacts were observed in the backdirt.

Recommendations: $\quad$ Monitor revegetation efforts in October.

Attach additional documentation, as warranted (photos, profiles, etc.)

Yes $\mathrm{X}$ No If yes, describe: photographs

Initials: $\quad B R P$ BRP
Date:

August 28 - 30, 2007

September 4 - 6, 2007 
Appendix A: Historic Trails and Stage Stations 
Monitor Number:
Monitor Name(s):
Monitor Date:

HKG-05

Hollie Gilbert, Julie Braun

April 26, 2007

Site Name/Number:

Goodale's Cutoff / T-1

Reason for monitoring: Routine check

Findings: $\quad$\begin{tabular}{|l|l|l|l|}
\hline Type 1 & $\mathrm{x}$
\end{tabular}$\quad$\begin{tabular}{|l|l|l|}
\hline Type 2 & Type 3 \\
\hline
\end{tabular}

Impact Agent(s): $\quad$ No new impacts, however, BLM road grading activities that occurred in 2002 from the point were T-1 crosses the western INL border, and continuing for several miles east onto the INL, are still very visible.

Significance of Impact:

Did disturbance or impact extend into undisturbed areas?

If yes, describe:
Work Halted?
If yes, describe:

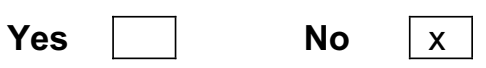

Notifications: $\quad$ N/A

Primary contact(s): N/A

Date contacted: N/A

Contact Method: E-mail

Cultural Materials observed? Yes $x$ No $\quad$

If yes, describe: Various lithic scatters were noted along the route; however they were not formerly monitored. Places along the route that cross basalt ridges where the road is rough were spot checked for artifacts; horse shoe nails and other various pieces of metal were observed. The basalt rocks in these areas also show extensive wear from wagon wheels and in some cases iron/rust stains are still visible on their surfaces and in the rock vesicles. It should also be noted that there are other visible sections (small side routes) that weave in and out along the entire current route.
Cultural Materials collected?
Yes
No $x$

If yes, describe:

General Comments:

Recommendations: Monitor annually

Attach additional documentation, as warranted (photos, profiles, etc.) $\quad$ Yes $\square$ No $\quad x$ If yes, describe:

Initials: $\quad$ HKG

Date: April 26, 2007 


\section{Monitor Number: Monitor Name(s): Monitor Date:}

BRP-02

Brenda R. Pace, Hollie Gilbert, Julie Braun April 17, 2007

Site Name/Number: Reason for monitoring:

Road T-16 (Historic Trail)

Reported impacts from sheep grazing, check on project compliance with cultural resource recommendations

Findings:

\begin{tabular}{|l|l|}
\hline Type 1 & \\
\hline
\end{tabular}

\begin{tabular}{|l|l|}
\hline Type 2 & $\mathrm{X}$ \\
\hline
\end{tabular}

\section{\begin{tabular}{|l|l|}
\hline Type 3 & \\
\hline
\end{tabular}}

Type 4

Impact Agent(s): Significance of Impact:
Sheep, water trucks, vehicles, sheepherder camping

Impacts from grazing have been going on for a very long time but seem to be more severe this year. Any archaeological site, historic or prehistoric, that is located along the road has been significantly impacted this year.

Did disturbance or impact extend into undisturbed areas?

Yes $\mathrm{X}$ No

If yes, describe: Roadside is heavily impacted; trail has become deeply rutted with significant accumulations of dust; new vehicle tracks are established around low muddy spots, new sheep camps have been established in several areas along the road.

\begin{tabular}{lll|} 
Work Halted? & Yes \\
& & No $\mathrm{X}$ \\
\hline
\end{tabular}

If yes, describe: N/A

Notifications: $\quad$ Dept. of Energy

Primary contact(s): Robert Gallegos

Date contacted: April 17, 2007

Contact Method: $\quad$ E-mail $\quad \mathrm{X}$ Phone $\quad \mathrm{X}$ Official correspondence, CCN\#:

Cultural Materials observed? Yes $\mathrm{X}$ No

If yes, describe: Numerous homesteads are known to exist along T-16 as well as unrecorded lithic scatters.

Cultural Materials collected? Yes $\square$ No $\mathrm{X}$ If yes, describe: $\mathrm{N} / \mathrm{A}$

General Comments: Impacts will likely re-occur next Spring when grazers return.

Recommendations: 1 ) Survey and formally record historic and prehistoric sites along roadway to establish baseline for future monitoring; 2) consider adding additional gravel to road surface to keep vehicles on the road; 3 ) establish designated campsites for grazers; 4) assess impacts from grazing across entire site and develop mitigation activities for ongoing adverse impacts.

Attach additional documentation, as warranted (photos, profiles, etc.) $\quad$ Yes $\square$ No $\quad X$ If yes, describe:

Initials: $\quad B R P$

Date: April 16, 2007 
Monitor Name(s):

Monitor Date:

Hollie Gilbert, Julie Braun

April 20, 2007

Site Name/Number: $\quad$ 10-BT-2194 / Powell Stage Station

Reason for monitoring: Routine check

\begin{tabular}{l|l|l|l|l|}
\hline Findings: & Type 1 & Type 2 & $\mathrm{x}$ & Type 3 \\
\hline
\end{tabular}

Impact Agent(s): $\quad$ Badger / rodent burrowing

Significance of Impact: $\quad$ Does not affect sites eligibility

Did disturbance or impact extend into undisturbed areas?

Yes $\square$ No $\mathrm{x}$

If yes, describe:

Work Halted?

If yes, describe:

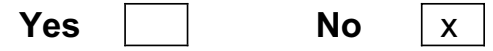

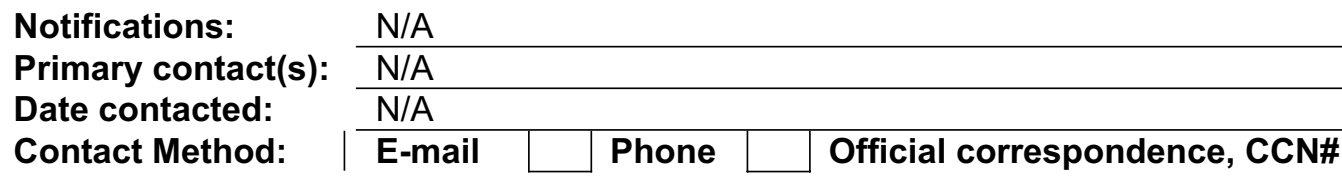

Cultural Materials observed? Yes $x$ No

If yes, describe: An apparent badger is burrowing in the southeast corner of the stage station's rock foundation, exposing more of the basalt foundation; also a piece of unidentified metal was unearthed. This disturbance could impact the remaining structure of the southeast corner.

Cultural Materials collected? Yes $\square$ No $\mathrm{x}$

If yes, describe:

General Comments: The area is still recovering from a 2000 wildlands fire. Grasses are predominant. Also DOE's floodplain trenching project is in close proximity to the site. CRM monitoring is recommended when trenches are back filled and during re-vegetation efforts.

Recommendations: Monitor annually

Attach additional documentation, as warranted (photos, profiles, etc.) $\quad$ Yes $x$ No If yes, describe:

Initials: HKG

Date: April 20, 2007 
Monitor Number:

Monitor Name(s):

Monitor Date:

CFM-04

Clayton Marler, Dino Lowrey, Robert Gallegos, Julie Braun 4/12/07; 5/31/07

Site Name/Number:

Powell Stage Station

Reason for monitoring: Routine

Findings:

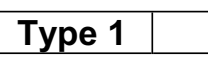

\begin{tabular}{|l|l|}
\hline Type 2 & $\mathrm{x}$ \\
\hline
\end{tabular}

\begin{tabular}{|l|l|}
\hline Type 3 & \\
\hline
\end{tabular}

Type 4

Impact Agent(s): $\quad$ Animal burrowing (probable badger) inside foundations.

Significance of Impact: $\quad$ Impact does not affect the site's NRHP eligibility

Did disturbance or impact extend into undisturbed areas?

Yes

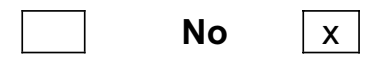

If yes, describe:

Work Halted?

Yes

No

If yes, describe:

Notifications:

Primary contact(s):

Date contacted:

Contact Method:

| E-mail $\square$ Phone $\square$ Official correspondence, CCN\#:

Cultural Materials observed? Yes $\mathrm{x}$

No

If yes, describe: Dense historic debris, basalt foundations

Cultural Materials collected?

Yes

No $x$

If yes, describe:

General Comments:

Recommendations: Continue monitoring once per year.

Attach additional documentation, as warranted (photos, profiles, etc.) $\quad$ Yes $X$ No $\quad$ N If yes, describe: Photos

Initials: $\quad$ CFM

Date: $\quad 4 / 12 / 07 ; 5 / 31 / 07$ 


\begin{abstract}
Monitor Number: Monitor Name(s): Monitor Date:
\end{abstract}

HKG-09

Hollie Gilbert, Julie Braun August 21, 2007

Site Name/Number:

BEA-07-32-115 / Birch Creek Stage Station

Reason for monitoring: Historic sites re-evaluation project

\begin{tabular}{l|l|l|l|l|}
\hline Findings: & Type 1 & Type 2 & $x$
\end{tabular}$\quad$\begin{tabular}{|l|l|l|}
\hline Type 3 & Type 4 \\
\hline
\end{tabular}

Impact Agent(s): $\quad$ Sheep grazing, possible unauthorized visitation.

Significance of Impact: $\quad$ Current impacts do not threaten this site's eligibility status.

Did disturbance or impact extend into undisturbed areas?

Yes $\square$ No $\mathrm{x}$

If yes, describe:

Work Halted?

If yes, describe:

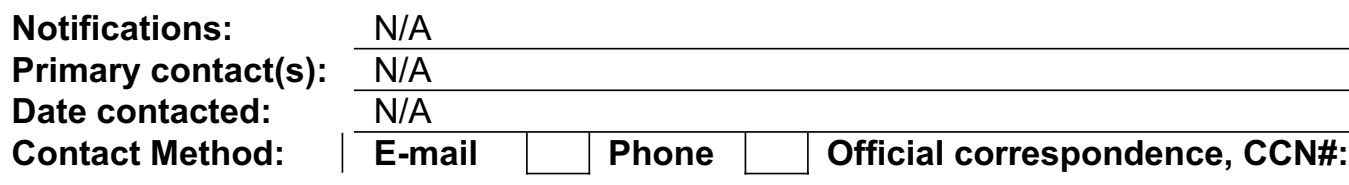

Cultural Materials observed? Yes $\mathrm{x}$ No

If yes, describe: Structural features are still visible; house foundation and other features such as possible flower bed borders with walk way and dugout. The soils where it is assumed the barn/corrals were is still devoid of vegetation except for halogeton and very scant short grasses. Typical historical artifacts (i.e., broken glass, nails, and cans) distributed throughout area. Additional items noted are window pane glass, square nails, and decorative cast iron stove pieces.

Cultural Materials collected? Yes $\mathrm{x}$ No $\square$

If yes, describe: An 1889 Liberty Seated dime was found in association with the dugout/root cellar. Because of the accessibility of this site to the public, i.e., located with the Hunting and Grazing Boundaries, this artifact was collected.

General Comments: Apparently this area is used annually for a temporary sheep camp. This activity has not directly impacted the site's structural remains however it could pose as a threat in the future. Sheep disturbance is noted to be on the northern periphery of the site's general area. Julie added, that although sheep have impacted the area (i.e., vegetation and dense scat covering in areas), sheep herding activities should be considered a historic activity for the area, and therefore keeping a tradition alive for the area.

Recommendations: Monitor annually

Attach additional documentation, as warranted (photos, profiles, etc.) Yes $\square$ No $\square$ If yes, describe:

Initials: $\quad H K G$

Date: August 21, 2007 
Appendix A: Historic Homesteads 


\begin{abstract}
Monitor Number: Monitor Name(s): Monitor Date:
\end{abstract}

HKG-01

Hollie Gilbert, Julie Braun April 15, 2007

Site Name/Number: 10-JF-170/ISU-89-2-A18 Reason for monitoring:

Historic sites re-evaluation project

Findings:

\begin{tabular}{|l|l|}
\hline Type 1 & \\
\hline
\end{tabular}

\begin{tabular}{|l|l|}
\hline Type 2 & $\mathrm{x}$ \\
\hline
\end{tabular}

\begin{tabular}{|l|l|}
\hline Type 3 & \\
\hline
\end{tabular}

Type 4

Impact Agent(s): $\quad$ Sheep grazing, possible unauthorized visitation.

Significance of Impact: $\quad$ Current impacts do not threaten this site's eligibility status.

Did disturbance or impact extend into undisturbed areas? If yes, describe:

Yes $\square$ No $\mathrm{x}$

Work Halted?

If yes, describe:

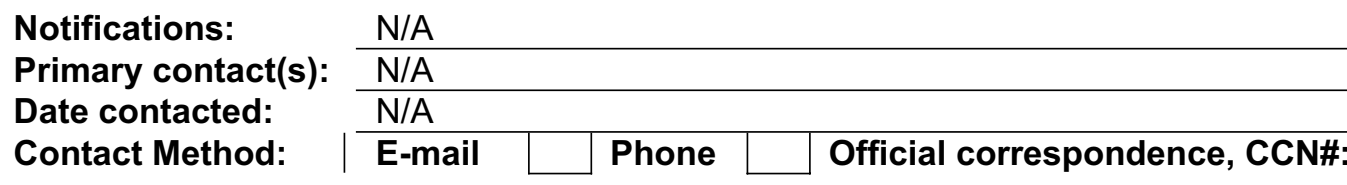

Cultural Materials observed? Yes $x$ No $\square$

If yes, describe: Artifacts previously recorded plus one complete purpled medicine bottle (cc measurements on side of bottle), coal pieces associated with a nail concentration, stove pipe flashing, stove pipe and window pane glass. A large area to the north looks to be historically disturbed; potentially a corralling area with fence posts. Recent Pepsi cans have been deposited on site. Area appears to have been used for sheep grazing recently. Orange nylon bailing line was also noted.

\begin{tabular}{lll} 
Cultural Materials collected? & Yes \\
If yes, describe: & No & $x$ \\
\hline
\end{tabular}

General Comments: This site was relocated during an ongoing effort to re-evaluate previously recorded historic sites. The initial site form describes a $30 \mathrm{~cm}$. depression from possible recent looting; however, the size of the sagebrush growing on the back fill pile suggests that the depression could be part of the original site.

Recommendations: Since looting is not suspected, and sheep grazing is an ongoing historical activity for this area, monitoring does not need to occur annually, but should be considered again in the future.

Attach additional documentation, as warranted (photos, profiles, etc.) $\quad$ Yes $\square$ No \begin{tabular}{|l|l|}
\hline \\
\hline
\end{tabular} If yes, describe:

Initials: HKG

Date: April 15, 2007 
Monitor Number:
Monitor Name(s):
Monitor Date:

HKG-04

Hollie Gilbert, Julie Braun

April 25, 2007

Site Name/Number:

10-BT-1474 / ISU-89-2-A8

Reason for monitoring:

Historic sites re-evaluation project

Findings:

\begin{tabular}{|l|l|}
\hline Type 1 & $x$ \\
\hline
\end{tabular}

\begin{tabular}{|l|l|}
\hline Type 2 & \\
\hline
\end{tabular}

\begin{tabular}{|l|l|}
\hline Type 3 & \\
\hline
\end{tabular}

Type 4

Impact Agent(s):

Potential Big Lost River flooding, however this has not been evaluated or confirmed.

Significance of Impact: $\quad$ Site retains integrity and therefore eligibility.

Did disturbance or impact extend into undisturbed areas?

Yes $\mathrm{x}$ No

If yes, describe: Broad area surrounding site is impacted by flooding.

$\begin{array}{llll}\text { Work Halted? } & \text { Yes } & & \text { No }\end{array}$

If yes, describe:

Notifications: $\quad$ N/A

Primary contact(s): N/A

Date contacted: $\quad$ N/A

Contact Method:

| E-mail $\quad \square$ Phone $\square$ Official correspondence, CCN\#:

\section{Cultural Materials observed? Yes $\mathrm{x}$ No $\square$}

If yes, describe: Additional artifacts were noted from initial recordation in 1989. Additional artifacts included: coal, a shell button, heavy metal hardware (possible plow parts), large tablespoon, corset stays, rubber boot buckle, one complete 6 " aqua colored bottle ( 2 piece mold, concave sides with bubbles with "Dr. S. PITCHER'S CASTORIA" embossed, additional wire nails and one outhouse sized depression.

Cultural Materials collected? Yes $\square$ No $x$

If yes, describe: N/A

General Comments: Most of the artifacts at this site are partially or mostly covered with soils. The site is adjacent to a channel of the Big Lost River just south of the Big Lost River Sinks. Site most likely impacted historically by flooding.

Recommendations: $\quad$ Potential impacts should be evaluated when flooding occurs in area.

Attach additional documentation, as warranted (photos, profiles, etc.) $\quad$ Yes $\square$ No $\quad x$ If yes, describe:

Initials: $\quad$ HKG

Date: April 25, 2007 
Monitor Number: $\quad$ HKG 06

Monitor Name(s):

Monitor Date:

Hollie Gilbert, Julie Braun

April 26, 2007

Site Name/Number:

Field \# ISU-2002-M13

Reason for monitoring:

Historic sites re-evaluation project

Findings:

\begin{tabular}{|l|l|}
\hline Type 1 & $\mathrm{x}$ \\
\hline
\end{tabular}

\begin{tabular}{|l|l|}
\hline Type 2 & \\
\hline
\end{tabular}

\begin{tabular}{|l|l|}
\hline Type 3 & $\mathrm{x}$ \\
\hline
\end{tabular}

Type 4

Impact Agent(s): Looting

Significance of Impact: $\quad$ Does not affect sites eligibility

Did disturbance or impact extend into undisturbed areas?

If yes, describe:

Yes No No $\quad \square$

Work Halted?

If yes, describe:

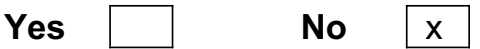

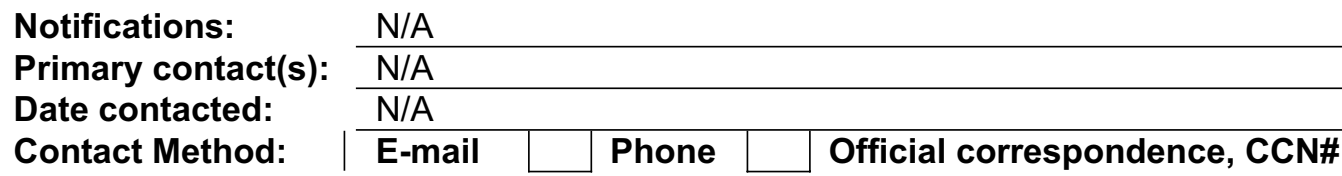

Cultural Materials observed? Yes $\mathrm{x}$ No

If yes, describe: Trash scatter previously recorded is still intact except for a large yellow tea kettle. Julie was involved in the initial recording of this site in 2002 and remembered a road construction crew in the immediate area during recordation. The tea kettle was drawn and described in detail.

Cultural Materials collected? Yes $\square$ No $\mathrm{x}$

If yes, describe:

General Comments:

Recommendations: At this point, the remaining trash scatter contains no other items that might be appealing to would-be collectors, therefore further monitoring is not recommended.

Attach additional documentation, as warranted (photos, profiles, etc.) $\quad$ Yes $\square$ No $\quad x$ If yes, describe:

Initials: $\quad H K G$

Date: April 26, 2007 
Monitor Name(s):

Monitor Date:

Hollie Gilbert, Julie Braun

August 21, 2007

Site Name/Number: $\quad$ Kuharski Homestead/Field \# BEA-07-32-114

Reason for monitoring: Routine monitoring

Findings:

\begin{tabular}{|l|l|}
\hline Type 1 & \\
\hline
\end{tabular}

\begin{tabular}{|l|l|}
\hline Type 2 & $\mathrm{x}$ \\
\hline
\end{tabular}

Type 3

Type 4

Impact Agent(s): $\quad$ Badger / rodent burrowing

Significance of Impact: $\quad$ Does not affect sites eligibility

Did disturbance or impact extend into undisturbed areas?

Yes No $\quad \mathrm{x}$

If yes, describe:

Work Halted?

If yes, describe:

Notifications: $\quad$ N/A

Primary contact(s): N/A

Date contacted: $\quad \mathrm{N} / \mathrm{A}$

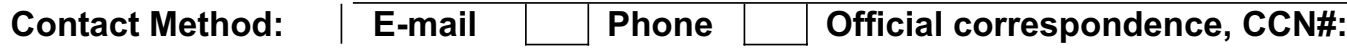

Cultural Materials observed? Yes $x$ No

If yes, describe: Just south of the house foundation is a concentration of brick which potentially could have been a blacksmithing forge. The borrowing occurred in this area exposing buried bricks, large chunks of charcoal, and burned wood.

$\begin{array}{llll}\text { Cultural Materials collected? } & \text { Yes } \\ & \text { No } \quad x\end{array}$

If yes, describe:

General Comments:

Recommendations:

Because of this sites close proximity to public lands, and the potential for further rodent damage, it should be monitored annual.

Attach additional documentation, as warranted (photos, profiles, etc.)

Yes $x$

No

If yes, describe:

Initials: $\quad H K G$

Date: August 21, 2007 
Monitor Number:

Monitor Name(s):

Monitor Date:

HKG-10

Hollie Gilbert, Brenda Pace

September 27, 2007

Site Name/Number:

Field \# BEA-05-44-10

Reason for monitoring:

Fire reconnaissance, historic sites re-evaluation project

Findings:

\begin{tabular}{|l|l|}
\hline Type 1 & \\
\hline
\end{tabular}

\begin{tabular}{|l|l|}
\hline Type 2 & $\mathrm{x}$ \\
\hline
\end{tabular}

Type 3

Type 4

Impact Agent(s): $\quad$ East Butte Fire (7/19/07)

Significance of Impact: $\quad$ Does not affect sites eligibility

Did disturbance or impact extend into undisturbed areas?

Yes $\mathrm{x}$ No

If yes, describe: $\quad 8715$ acres burned in this wildlands fire.

Work Halted?

If yes, describe:

Yes $\square$ No $x$

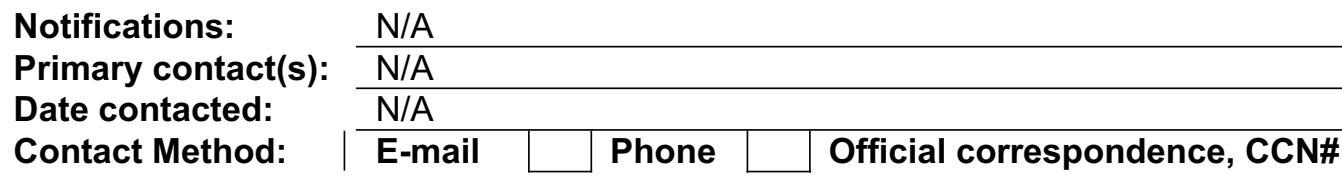

$\begin{array}{llll}\text { Cultural Materials observed? Yes } & x & \text { No }\end{array}$

If yes, describe: $\quad$ Although area is totally devoid of vegetation due to the fire, milled lumber is still present from the original structure. Additional artifacts encountered include bailing wire and an excavated depression located approximately 30 meters to the northwest.

Cultural Materials collected? Yes $\square$ No $\quad \mathrm{x}$

If yes, describe:

General Comments: Fire may have increased the fragility of individual artifacts but has not adversely affected the site as a whole.

Recommendations: $\quad$ At this time, no further monitoring is necessary.

Attach additional documentation, as warranted (photos, profiles, etc.) $\quad$ Yes $x$ No If yes, describe:

Initials: $\quad H K G$

Date: September 27, 2007 


\begin{abstract}
Monitor Number: Monitor Name(s): Monitor Date:
\end{abstract}

HKG-11

Hollie Gilbert, Brenda Pace

September 27, 2007

Site Name/Number:

Field \# BEA-05-44-11

Reason for monitoring:

Fire reconnaissance, historic sites re-evaluation project

Findings:

Type 1

\begin{tabular}{|l|l|}
\hline Type 2 & $\mathrm{x}$ \\
\hline
\end{tabular}

Type 3

Type 4

Impact Agent(s): $\quad$ East Butte Fire (7/19/07)

Significance of Impact: $\quad$ Does not affect sites eligibility

Did disturbance or impact extend into undisturbed areas?

Yes $\mathrm{x}$ No

If yes, describe: $\quad 8715$ acres burned in this wildlands fire.

Work Halted?

If yes, describe:

Notifications:

Primary contact(s):

Date contacted:

Contact Method:

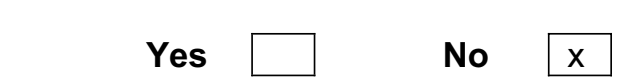

Cultural Materials

If yes, describe:
$\mathrm{N} / \mathrm{A}$
$\mathrm{N} / \mathrm{A}$
N/A
| E-mail $\square$ Phone $\square$ Official correspondence, CCN\#:

observed? Yes $x$ No $\square$

Initial recordation of this site occurred in 2005. Based on early 1918 survey maps, the location of this site was determined to be located west of the access road into the site. The 2005 survey concentrated only on the west side of the road. The 2007 fire exposed an extensive debris scatter on the east side of the road that was not initially located. Additional artifacts were also noted on the west side of the road. See recommendations below.

Cultural Materials collected? Yes $\square$ No $x$ If yes, describe:

General Comments: Fire may have increased the fragility of individual artifacts but has not adversely affected the site as a whole.

Recommendations: It is recommended that this site be re-recorded since the lack of vegetation has exposed an extensive domestic debris scatter not previously recorded. Recordation should occur either in the fall of 2007 or early spring 2008 before the area re-vegetates.

Attach additional documentation, as warranted (photos, profiles, etc.) $\quad$ Yes $\square$ No $\quad x$ If yes, describe:

Initials: $\quad$ HKG

Date: September 27, 2007 
Monitor Name(s):

Monitor Date:

Hollie Gilbert, Brenda Pace
September 27, 2007

Site Name/Number:

Field \# BEA-05-44-12

Reason for monitoring:

Fire reconnaissance, historic sites re-evaluation project

Findings:

\begin{tabular}{|l|l|}
\hline Type 1 & \\
\hline
\end{tabular}

\begin{tabular}{|l|l|}
\hline Type 2 & $\mathrm{x}$ \\
\hline
\end{tabular}

Type 3

Type 4

Impact Agent(s): $\quad$ East Butte Fire (7/19/07)

Significance of Impact: $\quad$ Does not affect sites eligibility

Did disturbance or impact extend into undisturbed areas?

Yes $\mathrm{x}$ No

If yes, describe: $\quad 8715$ acres burned in this wildlands fire.

Work Halted?

If yes, describe:

Yes $\square$ No $x$

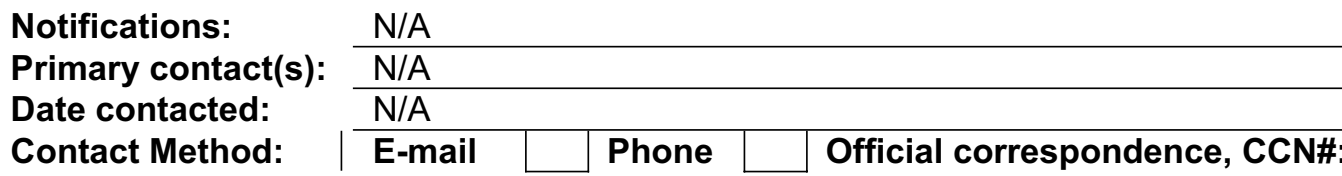

Cultural Materials observed? Yes $x$ No $\quad$

If yes, describe: Although the area is totally devoid of vegetation due to the fire, milled lumber is still present. Four additional cans were also located (for a total of six cans) as well as two distinct window pane glass scatters. One strand of bailing wire was also noted. Additionally, the fire exposed two linear basalt rock alignments (probable house foundation) that were not previously noted in 2005 recordation. A dense scatter of wire nails surrounds the foundation and roofing nails were also noted.

Cultural Materials collected? Yes $\square$ No $\mathrm{x}$

If yes, describe:

General Comments: Fire may have increased the fragility of individual artifacts but has not adversely affected the site as a whole.

Recommendations: At this time, no further monitoring is necessary.

Attach additional documentation, as warranted (photos, profiles, etc.) Yes $\quad x \quad$ No $\square$ If yes, describe:

Initials: HKG

Date: September 27, 2007 
Monitor Number: $\quad$ BRP-10

Monitor Name(s):

Monitor Date:

Brenda R. Pace, Wendy Savkranz

August 6, 2007

Site Name/Number:

10-BT-269

Reason for monitoring: $\quad$ Confirmation of site location in relation to proposed project activities

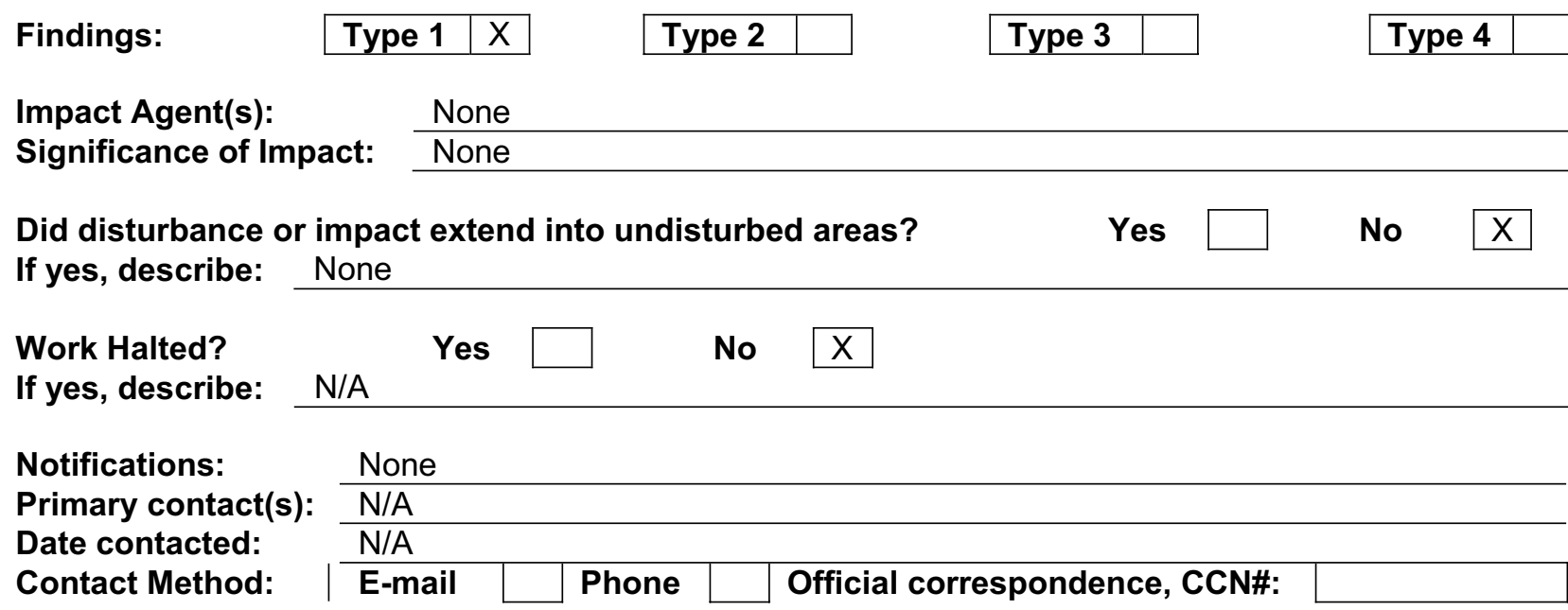

Cultural Materials observed? Yes $\mathrm{X}$ No

If yes, describe: Site includes rusted cans, purpled glass, other glass, china fragments, stove parts, lamp parts, a foundation made of basalt, depressions that may mark other cultural features, and a ditch. Old aerial photos show field scars as well.

Cultural Materials collected? Yes $\square$ No $\mathrm{X}$

If yes, describe: N/A

General Comments: $\quad$ Site has not been directly impacted by nearby projects, including the newest, a concrete batch plant. A wire fence placed around the site during construction of the nearby stormwater ponds is in disrepair but the posts are still solid.

Recommendations: $\quad$ Continue monitoring at this location given plans for intensive activities in the area. Repair fence and install signs.

Attach additional documentation, as warranted (photos, profiles, etc.) $\quad$ Yes $\square$ No $\quad$ X If yes, describe:

Initials: $\quad$ BRP

Date: August 6, 2007 


\begin{abstract}
Monitor Number: Monitor Name(s): Monitor Date:
\end{abstract}

BRP-05

Brenda R. Pace, Hollie Gilbert, Julie Braun March 22 - July 31, 2007
Site Name/Number: Reason for monitoring:

LMIT-99-08-12

Magnetometer surveys for unexploded ordnance (UXO) are utilizing a 6-Wheeler and a lightweight cart offroad to identify buried UXO and flag it for future remediation. These project activities are being monitored to determine if the offroad activity results in impacts to known historic and prehistoric archaeological sites.
Findings:
\begin{tabular}{|l|l|}
\hline Type 1 & $\mathrm{X}$ \\
\hline
\end{tabular}
Type 2
Type 3
Type 4
Impact Agent(s):
6-Wheeler/cart driving offroad, animal activity
Significance of Impact:

\begin{tabular}{l}
\hline Vehicle and cart leave shallow tracks through soft surface soils but do not \\
\hline impact harder gravel deposits. Impacts to ground surfaces appear to be \\
\hline minimal, not much greater than intensive pedestrian activity. All surface soils \\
\hline in this area are heavily impacted by gophers, ground squirrels, and badgers. \\
\hline
\end{tabular}

Did disturbance or impact extend into undisturbed areas?

Yes $\mathrm{X}$

No

If yes, describe: At the present time, 6 -Wheeler/cart surveys are restricted to areas previously surveyed for archaeological resources to assess impact and suitability for limited future deployment in unsurveyed areas. These areas are largely undisturbed.

Work Halted?

If yes, describe:

\begin{abstract}
Yes
\end{abstract}
No

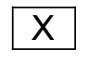

Notifications:

Primary contact(s):

Date contacted:

Contact Method:

N/A

Cultural Materials observed?

None

If yes, describe: Extensive concentration of can Official correspondence, CCN\#:

$\mathrm{N} / \mathrm{A}$

$\mathrm{N} / \mathrm{A}$

E-mail Phone

No $\square$

\title{
Yes $\mathrm{X}$
}

ceramics, and other metal artifacts. Features

(foundations, cellar, etc.) are indicated by basalt cobbles and depressions.

Cultural Materials collected?

Yes

No $X$

If yes, describe: $\mathrm{N} / \mathrm{A}$

General Comments: $\quad$ On the floodplain deposits around NODA, offroad use of the 6-Wheeler and cart does not appear to adversely impact historic or prehistoric archaeological sites.

Faint tracks are visible through softer soils, but not on flood gravels. No surface artifacts were displaced or broken. Impacts are comparable to intensive foot traffic. Geophysical data collected from the site area may be valuable in identifying additional hidden cultural features at this site.

Recommendations: Conduct additional monitoring if subsurface ordnance are flagged for cleanup/ remediation inside the boundaries of this site. Analyze geophysical data (magnetometer) collected from this location during the survey.

Attach additional documentation, as warranted (photos, profiles, etc.)

Yes $\mathrm{X}$ No If yes, describe: photographs

Initials: $\quad B R P$

Date: June 10, 2007 


\section{Appendix A: World War II Sites}




\begin{abstract}
Monitor Number: Monitor Name(s): Monitor Date:
\end{abstract}

JBB-02

Julie Braun, Hollie Gilbert, Tom Wheeler November 16, 2007

Site Name/Number: CFA-607/Commanding Officers Quarters

Reason for monitoring: Routine check

\begin{tabular}{l|l|l|l|l|}
\hline Findings: & Type 1 & & Type 2 & $\mathrm{X}$
\end{tabular}$\quad$\begin{tabular}{|l|l|l|}
\hline Type 3 & \\
\hline
\end{tabular}

Impact Agent(s): $\quad$ See attached Table

Significance of Impact: See attached Table

Did disturbance or impact extend into undisturbed areas?

If yes, describe:

Work Halted?

If yes, describe:

Yes $\square$ No $\mathrm{X}$

Notifications:

Primary contact(s):

Date contacted:

Contact Method:

BEA Facility Management

Tom Wheeler

November 16, 2006

Contact Method:

\begin{tabular}{|l|l|l}
\hline E-mail & $\begin{array}{l}\text { X with } \\
\text { report } \\
\text { attached }\end{array}$ & Phone \\
\cline { 2 - 3 } &
\end{tabular}

Yes

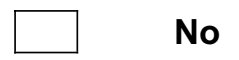

No $\mathrm{X}$

\section{Cultural Materials observed? Yes $\mathrm{X}$ No $\square$}

If yes, describe: Initially constructed as the base commander's residence, Building CF-607 appears to be either a wood framed or clay tile one story structure with a brick veneer supported by a concrete foundation. There is a partial basement for mechanical and utilities. Historic Fabric: The majority of this building's exterior appears to be original, with the exception of alterations to the entry steps and entry way. The brick, concrete foundation, wood-framed gables and associated trim, wood windows and doors retain a high degree of original character and design. The alterations of the entry way appear inconsistent with the scale and texture of the building. Interior wall surfaces appear to have been overbuilt with later materials, losing definition and detail around many windows. It is unknown whether the original wall covering was retained under the alteration. Many other interior elements, like wood trim, built-in cabinets, and fixtures, reflect original construction. Minor partition additions and deletions have occurred from changing use.

\section{Cultural Materials collected? \\ Yes \\ No $\mathrm{X}$}

If yes, describe:

General Comments: No new impacts have occurred and the eligibility is not affected; however, a lack of routine maintenance continues to add to cumulative impacts.

Recommendations: See attached table for recommended treatments.

Attach additional documentation, as warranted (photos, profiles, etc.) Yes $\mathrm{X}$ No If yes, describe: photos

Initials: JBB

Date: November 16, 2007 


\begin{tabular}{|c|c|c|c|c|c|}
\hline Problem & Probable Cause & $\begin{array}{l}\text { Testing and } \\
\text { Investigation }\end{array}$ & $\begin{array}{l}\text { Impact on the } \\
\text { Structure }\end{array}$ & Treatment & Priority \\
\hline $\begin{array}{l}\text { Extreme } \\
\text { temperature } \\
\text { fluctuations }\end{array}$ & $\begin{array}{l}\text { All utilities } \\
\text { disconnected }\end{array}$ & Visual & $\begin{array}{l}\text { Deterioration of } \\
\text { historic fabric } \\
\text { (i.e., bulging } \\
\text { ceiling tiles) }\end{array}$ & $\begin{array}{l}\text { Regulate } \\
\text { temperatures }\end{array}$ & High \\
\hline $\begin{array}{l}\text { Cobwebs, } \\
\text { animal } \\
\text { droppings, } \\
\text { bird, hornet } \\
\text { nests near } \\
\text { entry }\end{array}$ & $\begin{array}{l}\text { Minimal } \\
\text { maintenance } \\
\text { over past } \\
\text { several years }\end{array}$ & Visual & $\begin{array}{l}\text { Bird droppings } \\
\text { cause } \\
\text { deterioration, } \\
\text { shabby } \\
\text { appearance }\end{array}$ & $\begin{array}{l}\text { Clean, remove } \\
\text { nests, exterminate }\end{array}$ & Medium \\
\hline $\begin{array}{l}\text { Roof } \\
\text { shingles are } \\
\text { cracking }\end{array}$ & Lack of oil & Visual & $\begin{array}{l}\text { Could cause roof } \\
\text { deterioration and } \\
\text { leaking }\end{array}$ & $\begin{array}{l}\text { Oil shingles/ } \\
\text { replace broken } \\
\text { shingles }\end{array}$ & High \\
\hline $\begin{array}{l}\text { Leaking } \\
\text { window pane } \\
\text { in front door }\end{array}$ & $\begin{array}{l}\text { Loss of seal } \\
\text { around window }\end{array}$ & Visual/touch/smell & $\begin{array}{l}\text { Water on } \\
\text { floor/wet carpet } \\
\text { and hardwood }\end{array}$ & $\begin{array}{l}\text { Caulk window or } \\
\text { replace } \\
\text { nonoriginal door }\end{array}$ & Medium \\
\hline $\begin{array}{l}\text { Cracked } \\
\text { window pane } \\
\text { room } 103, \\
\text { eastside of } \\
\text { basement }\end{array}$ & $\begin{array}{l}\text { Water } \\
\text { intrusion/Lack } \\
\text { of maintenance }\end{array}$ & Visual & $\begin{array}{l}\text { Deterioration of } \\
\text { window sash }\end{array}$ & $\begin{array}{l}\text { Replace and } \\
\text { reglaze pane }\end{array}$ & High \\
\hline $\begin{array}{l}\text { Cracked and } \\
\text { peeling walls }\end{array}$ & Water intrusion & Visual/touch & $\begin{array}{l}\text { Deterioration of } \\
\text { original fabric }\end{array}$ & $\begin{array}{l}\text { Install/repair } \\
\text { water gutter } \\
\text { drainage system, } \\
\text { install window } \\
\text { well covers }\end{array}$ & High \\
\hline $\begin{array}{l}\text { Tree growing } \\
\text { in west } \\
\text { window well }\end{array}$ & $\begin{array}{l}\text { Vegetation too } \\
\text { close to } \\
\text { foundation/lack } \\
\text { of maintenance }\end{array}$ & Visual & $\begin{array}{l}\text { Deterioration of } \\
\text { original fabric }\end{array}$ & $\begin{array}{l}\text { Remove tree, } \\
\text { cutback plants to } \\
2 \mathrm{ft} . \text { from } \\
\text { foundation }\end{array}$ & High \\
\hline $\begin{array}{l}\text { Dangling } \\
\text { light fixture }\end{array}$ & $\begin{array}{l}\text { Lack of } \\
\text { maintenance }\end{array}$ & Visual & Safety & $\begin{array}{l}\text { Remove light } \\
\text { fixture }\end{array}$ & High \\
\hline $\begin{array}{l}\text { Efflorescence } \\
\text { noted on } \\
\text { exterior brick }\end{array}$ & $\begin{array}{l}\text { Water, } \\
\text { leaching salt } \\
\text { from brick }\end{array}$ & Visual/touch & $\begin{array}{l}\text { Deteriorating } \\
\text { masonry }\end{array}$ & $\begin{array}{l}\text { Repair/replace } \\
\text { drainage system }\end{array}$ & High \\
\hline
\end{tabular}


Monitor Number:
Monitor Name(s):
Monitor Date:

JBB-03

Julie Braun, Hollie Gilbert, Tom Wheeler

November 16, 2007

Site Name/Number:

CFA-632/Garage

Reason for monitoring: Routine check

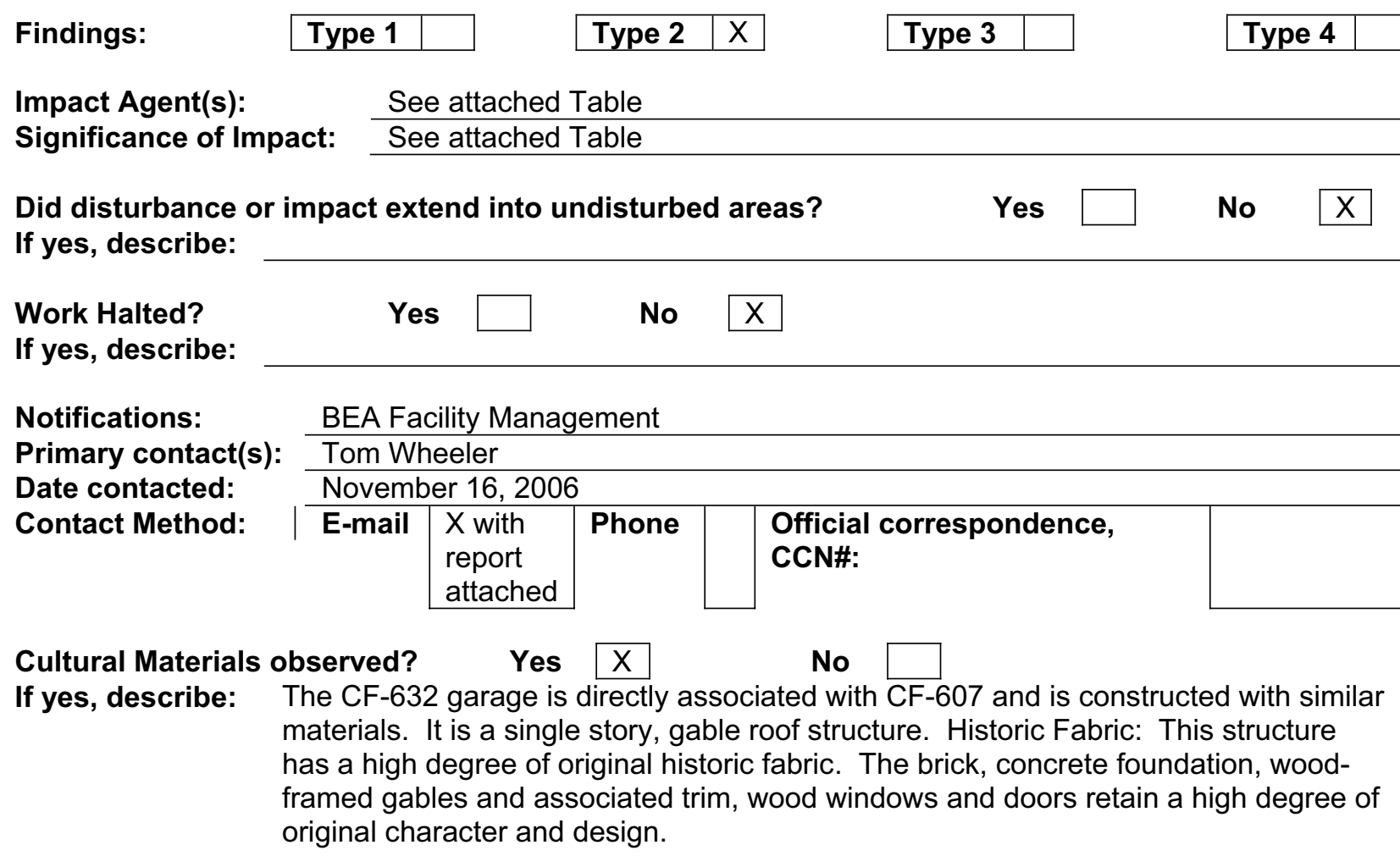

Cultural Materials collected? Yes $\square$ No $\quad$ X

If yes, describe:

General Comments: No new impacts have occurred and the eligibility is not affected; however, a lack of routine maintenance continues to add to cumulative impacts.

Recommendations: $\quad$ See attached table for recommended treatments.

Attach additional documentation, as warranted (photos, profiles, etc.) $\quad$ Yes $X \quad$ No $\square$ If yes, describe: photos

Initials: JBB

Date: November 16, 2007 


\begin{tabular}{|c|c|c|c|c|c|}
\hline Problem & Probable Cause & $\begin{array}{l}\text { Testing and } \\
\text { Investigation }\end{array}$ & $\begin{array}{l}\text { Impact on the } \\
\text { Structure }\end{array}$ & Treatment & Priority \\
\hline $\begin{array}{l}\text { Extreme } \\
\text { temperature } \\
\text { fluctuations }\end{array}$ & $\begin{array}{l}\text { All utilities } \\
\text { disconnected }\end{array}$ & Visual & $\begin{array}{l}\text { Deterioration of } \\
\text { historic fabric (i.e., } \\
\text { bulging ceiling } \\
\text { tiles) }\end{array}$ & $\begin{array}{l}\text { Regulate } \\
\text { temperatures }\end{array}$ & High \\
\hline $\begin{array}{l}\text { Bird, hornet } \\
\text { nests near } \\
\text { entry }\end{array}$ & $\begin{array}{l}\text { Minimal } \\
\text { maintenance } \\
\text { over past } \\
\text { several years }\end{array}$ & Visual & $\begin{array}{l}\text { Bird droppings } \\
\text { cause } \\
\text { deterioration, } \\
\text { shabby appearance }\end{array}$ & Remove nests & Medium \\
\hline $\begin{array}{l}\text { Peeling } \\
\text { wooden } \\
\text { garage door }\end{array}$ & $\begin{array}{l}\text { Water } \\
\text { adsorption/poor } \\
\text { drainage }\end{array}$ & Visual/touch & $\begin{array}{l}\text { Loss of historic } \\
\text { fabric }\end{array}$ & $\begin{array}{l}\text { Seal with } \\
\text { plywood/fix water } \\
\text { drainage problem }\end{array}$ & High \\
\hline $\begin{array}{l}\text { Peeling } \\
\text { paint on } \\
\text { exterior } \\
\text { trim }\end{array}$ & $\begin{array}{l}\text { Lack of } \\
\text { maintenance }\end{array}$ & Visual & $\begin{array}{l}\text { Deterioration of } \\
\text { historic fabric }\end{array}$ & $\begin{array}{l}\text { Scrape and paint } \\
\text { with historic } \\
\text { colors }\end{array}$ & Medium \\
\hline $\begin{array}{l}\text { Broken } \\
\text { window }\end{array}$ & $\begin{array}{l}\text { Lack of } \\
\text { maintenance }\end{array}$ & Visual & $\begin{array}{l}\text { Appearance/water } \\
\text { intrusion }\end{array}$ & $\begin{array}{l}\text { Replace/reglaze } \\
\text { window }\end{array}$ & High \\
\hline $\begin{array}{l}\text { Support } \\
\text { post is } \\
\text { loose }\end{array}$ & $\begin{array}{l}\text { Lack of } \\
\text { maintenance }\end{array}$ & Touch/visual & Appearance/safety & $\begin{array}{l}\text { Straighten and } \\
\text { tighten bolt }\end{array}$ & High \\
\hline
\end{tabular}


Monitor Number:

Monitor Name(s):

Monitor Date:

JBB-04

Julie Braun, Hollie Gilbert, Tom Wheeler

November 16, 2007

Site Name/Number:

CFA-606/Marine Barracks

Reason for monitoring: Routine check

Findings:

\begin{tabular}{|l|l|}
\hline Type 1 & \\
\hline
\end{tabular}

\begin{tabular}{|l|l|}
\hline Type 2 & $\mathrm{X}$ \\
\hline
\end{tabular}

Type 3

Type 4

Impact Agent(s):

Significance of Impact:

See attached Table

See attached Table

Did disturbance or impact extend into undisturbed areas?

If yes, describe:

Work Halted?

If yes, describe:

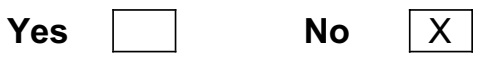

Notifications:

BEA Facility Management

Primary contact(s):

Date contacted:

Contact Method:

Tom Wheeler

November 16, 2006

\begin{tabular}{|c|c|c|c|}
\hline $\begin{array}{l}\text { E- } \\
\text { mail }\end{array}$ & $\begin{array}{l}\text { X with } \\
\text { report } \\
\text { attached }\end{array}$ & Phone & $\begin{array}{l}\text { Official correspondence, } \\
\text { CCN\#: }\end{array}$ \\
\hline
\end{tabular}

No

Cultural Materials observed? Yes $\mathrm{X}$

Yes $\square$ No $\mathrm{X}$

If yes, describe: Building CF-606 is a single story structure on a slightly raised full basement. In the original portion, the concrete basement supports solid brick walls with a simple gable roof and wood windows. A single story modern addition was added to the east half of the front façade in 1969. The addition appears to be concrete block and brick veneer. Historic Fabric: Originally, this building was designed with a symmetrical, linear façade. The 1969 addition to the front elevation has severely compromised the visual and material integrity of the historic character. Those areas of the original exterior still visible retain a high degree of historic material integrity through the brick, wood windows, wood trim, and roofing. The interior has undergone extensive alteration through various changes in use and operation

Cultural Materials collected?

Yes $\square$ No $\mathrm{X}$

If yes, describe:

General Comments:

Recommendations:

$\begin{array}{llll}\text { Attach additional documentation, as warranted (photos, profiles, etc.) } & \text { Yes } & X & \text { No }\end{array}$ If yes, describe: photos

Initials: JBB

Date: November 16, 2007 


\begin{tabular}{|c|c|c|c|c|c|}
\hline Problem & $\begin{array}{l}\text { Probable } \\
\text { Cause }\end{array}$ & $\begin{array}{l}\text { Testing and } \\
\text { Investigation }\end{array}$ & $\begin{array}{l}\text { Impact on the } \\
\text { Structure }\end{array}$ & Treatment & Priority \\
\hline $\begin{array}{l}\text { Extreme } \\
\text { temperature } \\
\text { fluctuations }\end{array}$ & $\begin{array}{l}\text { All utilities } \\
\text { disconnected }\end{array}$ & Visual & $\begin{array}{l}\text { Deterioration of } \\
\text { historic fabric (i.e., } \\
\text { bulging ceiling } \\
\text { tiles) }\end{array}$ & $\begin{array}{l}\text { Regulate } \\
\text { temperatures }\end{array}$ & High \\
\hline $\begin{array}{l}\text { Bird, hornet } \\
\text { nests near } \\
\text { entry }\end{array}$ & $\begin{array}{l}\text { Minimal } \\
\text { maintenance } \\
\text { over past } \\
\text { several years }\end{array}$ & Visual & $\begin{array}{l}\text { Bird droppings } \\
\text { cause } \\
\text { deterioration, } \\
\text { shabby appearance }\end{array}$ & Remove nests & Medium \\
\hline $\begin{array}{l}\text { Spalling } \\
\text { concrete in } \\
\text { entryway }\end{array}$ & $\begin{array}{l}\text { Water, } \\
\text { clogged and } \\
\text { missing } \\
\text { drainage } \\
\text { gutters }\end{array}$ & Visual & $\begin{array}{l}\text { Loss of fabric } \\
\text { (likely nonoriginal) }\end{array}$ & $\begin{array}{l}\text { Replace concrete } \\
\text { Clean gutters } \\
\text { regularly }\end{array}$ & High \\
\hline $\begin{array}{l}\text { Packrat } \\
\text { middens in } \\
\text { interior }\end{array}$ & $\begin{array}{l}\text { Minimal } \\
\text { maintenance }\end{array}$ & Visual/smell & Entry/exit holes & $\begin{array}{l}\text { Remove and plug } \\
\text { entry holes with } \\
\text { steel wool or } \\
\text { aluminum }\end{array}$ & High \\
\hline $\begin{array}{l}\text { Sawdust on } \\
\text { basement } \\
\text { floor }\end{array}$ & $\begin{array}{l}\text { Insects, } \\
\text { rodents }\end{array}$ & Visual & $\begin{array}{l}\text { Deterioration of } \\
\text { historic fabric }\end{array}$ & Exterminate & High \\
\hline $\begin{array}{l}\text { Water } \\
\text { stains in } \\
\text { basement }\end{array}$ & $\begin{array}{l}\text { Leaking } \\
\text { faucet, } \\
\text { clogged, } \\
\text { backed up } \\
\text { drains }\end{array}$ & Visual & $\begin{array}{l}\text { Deterioration of } \\
\text { historic fabric }\end{array}$ & Clean drains & Low \\
\hline $\begin{array}{l}\text { Crack in } \\
\text { foundation }\end{array}$ & $\begin{array}{l}\text { Tree growing } \\
\text { in stairwell }\end{array}$ & Visual & $\begin{array}{l}\text { Water/pest } \\
\text { intrusion }\end{array}$ & $\begin{array}{l}\text { Remove tree, } \\
\text { repair concrete }\end{array}$ & $\begin{array}{l}\text { High, } \\
\text { Medium }\end{array}$ \\
\hline
\end{tabular}




\begin{abstract}
Monitor Number: Monitor Name(s): Monitor Date:
\end{abstract}

JBB-05

Julie Braun, Hollie Gilbert, Tom Wheeler

November 16, 2007

Site Name/Number: CFA-613/Caretakers Residence

Reason for monitoring: Routine check
Findings:
Type 1
Impact Agent(s):
See attached Table
Significance of Impact: $\quad$ See attached Table

\begin{tabular}{|l|l|}
\hline Type 2 & $\mathrm{X}$ \\
\hline
\end{tabular}

Type 3

Type 4

Did disturbance or impact extend into undisturbed areas?

If yes, describe:

Work Halted?

If yes, describe:

Yes $\square$ No $\mathrm{X}$

Notifications:

Primary contact(s):

Date contacted:

Contact Method:

BEA Facility Management

Tom Wheeler

November 16, 2006

\begin{tabular}{|l|l|l}
\hline E-mail & $\begin{array}{l}\text { X with } \\
\text { report } \\
\text { attached }\end{array}$ & Phone \\
\cline { 2 - 3 } &
\end{tabular}

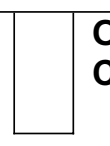

Official correspondence,
CCN\#:

Yes

$\square \quad$ No

No $\mathrm{X}$

\section{Cultural Materials observed? Yes $\mathrm{X}$ No}

If yes, describe: Building CF-613 is a single story, concrete and brick structure of residential scale. It has a full basement with concrete walls and a two wythe, 8" brick walls at the ground story, including brick walls at the roof gables. Internal partitions and roof framing are wood. The hand-split cedar shingle roof with associated ridge trim was installed ca. 1996. Historic Fabric: This structure has a high degree of original historic fabric, both interior and exterior. The exterior envelope of concrete foundation, brick exterior walls, exterior wood trim, and wood windows, along with the chimney and roof, have a high degree of integrity. The interior also has a high degree of historic fabric integrity in the form of wood trim, knotty pine paneling, period decorative cellotex wall board, and trim accessories. Alterations have affected some of the interior material through surface mounted electrical installations, painting, interior partitions (i.e., partition through the fireplace mantel)

Cultural Materials collected?

Yes

No $X$

If yes, describe:

General Comments: No new impacts have occurred and the eligibility is not affected; however, a lack of routine maintenance continues to add to cumulative impacts.

Recommendations: $\quad$ See attached table for recommended treatments.

Attach additional documentation, as warranted (photos, profiles, etc.)

Yes $X$ No If yes, describe: photos

Initials: JBB

Date: November 16, 2007 
Idaho National Laboratory Cultural Resource Management Office Field Monitoring Form

\begin{tabular}{|l|l|l|l|l|l|}
\hline Problem & Probable Cause & $\begin{array}{l}\text { Testing and } \\
\text { Investigation }\end{array}$ & $\begin{array}{l}\text { Impact on the } \\
\text { Structure }\end{array}$ & Treatment & Priority \\
\hline $\begin{array}{l}\text { Extreme } \\
\text { temperature } \\
\text { fluctuations }\end{array}$ & $\begin{array}{l}\text { All utilities } \\
\text { disconnected } \\
\text { historic fabric }\end{array}$ & Visual & $\begin{array}{l}\text { Regulate } \\
\text { temperatures }\end{array}$ & High \\
$\begin{array}{l}\text { Peeling paint, } \\
\text { exterior and }\end{array}$ & $\begin{array}{l}\text { Minimal } \\
\text { maintenance } \\
\text { over past several } \\
\text { years }\end{array}$ & Visual & $\begin{array}{l}\text { Deterioration of } \\
\text { underlying fabric }\end{array}$ & $\begin{array}{l}\text { Scrap and repaint } \\
\text { with historic colors }\end{array}$ & Medium \\
$\begin{array}{l}\text { Bowing and } \\
\text { collapsing } \\
\text { ceiling tiles }\end{array}$ & $\begin{array}{l}\text { Pest } \\
\text { intrusion/freeze } \\
\text { and thaw }\end{array}$ & Visual/smell & $\begin{array}{l}\text { Acoustic tile ceiling } \\
\text { is collapsing }\end{array}$ & $\begin{array}{l}\text { Remove pests, fill } \\
\text { entry holes with } \\
\text { steel wool/remove } \\
\text { ceiling tiles }\end{array}$ & High \\
$\begin{array}{l}\text { Wet exterior } \\
\text { masonry }\end{array}$ & $\begin{array}{l}\text { Clogged } \\
\text { drainage gutters }\end{array}$ & Visual & $\begin{array}{l}\text { Deteriorating } \\
\text { masonry }\end{array}$ & $\begin{array}{l}\text { Clean gutters } \\
\text { regularly }\end{array}$ & High \\
$\begin{array}{l}\text { Cracks in } \\
\text { foundation/west } \\
\text { basement wall }\end{array}$ & $\begin{array}{l}\text { Plants too close } \\
\text { to foundation, } \\
\text { watering } \\
\text { foundation }\end{array}$ & Visual & $\begin{array}{l}\text { Allows water entry } \\
\text { into basement }\end{array}$ & $\begin{array}{l}\text { Remove plants, fill } \\
\text { cracks with like } \\
\text { concrete, not } \\
\text { Portland Cement }\end{array}$ & Medium \\
\end{tabular}


Monitor Number:

Monitor Name(s):

Monitor Date:

CFM-08

Clayton Marler, Robert Gallegos, Julie Braun $5 / 31 / 07$

Site Name/Number: $\quad$ WW II dump site (BEA-08-05-CFM-01)

Reason for monitoring: Routine

Findings:

\begin{tabular}{|l|l|}
\hline Type 1 & $\mathrm{x}$ \\
\hline
\end{tabular}

Type 2

Type 3

Type 4

Impact Agent(s):

Significance of Impact:

Did disturbance or impact extend into undisturbed areas?

If yes, describe:

Yes $\square$ No

Work Halted?

If yes, describe:

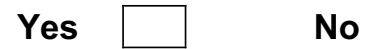

Notifications:

Primary contact(s):

Date contacted:

Contact Method:

| E-mail $\square$ Phone $\square$ Official correspondence, CCN\#:

Cultural Materials observed? Yes $x$

No

If yes, describe: Extensive and dense WW II-era trash scatter

Cultural Materials collected?

Yes

No $x$

If yes, describe:

General Comments:

Recommendations: This site should be formally recorded. Continue monitoring once per year.

Attach additional documentation, as warranted (photos, profiles, etc.) $\quad$ Yes $X$ No If yes, describe: Photo

Initials: $\quad$ CFM

Date: $\quad 5 / 31 / 07$ 
Appendix A: Experimental Breeder Reactor-I 
Monitor Number:
Monitor Name(s):
Monitor Date:

JBB-01

Julie Braun

May 10, 2007

Site Name/Number:

Experimental Breeder Reactor I

Reason for monitoring: Routine check
Findings:
\begin{tabular}{|l|l|}
\hline Type 1 & $\mathrm{X}$ \\
\hline
\end{tabular}
Type 2
Type 3
Type 4

Impact Agent(s):

Significance of Impact: $\quad$ No additional impacts to historic fabric have occurred. Technical problems do exist with the educational displays installed in 2005.

Did disturbance or impact extend into undisturbed areas?

If yes, describe:

\section{Work Halted?}

If yes, describe:

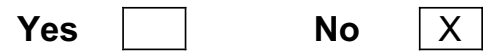

Notifications: $\quad$ BEA Facility Management, BEA Communications, Atomic Heritage Foundation

Primary contact(s): Dan Goulding, Don Miley, Cynthia Kelly

Date contacted: $\quad$ Summer 2007 (various dates)

\begin{tabular}{l|l|l|l|l|l} 
Contact Method: & E-mail & $\mathrm{X}$ & Phone & & Official correspondence, CCN\#:
\end{tabular}

Cultural Materials observed? Yes $\mathrm{X}$ No $\square$
If yes, describe: $\quad$ EBR I is a historic landmark and contains many historic features. It is a functional, multi-level industrial steel-frame structure in the Industrial Vernacular architectural style. It consists of a basement, ground floor, and mezzanine and is approximately 122 feet long by 77 feet wide. The height of the building above ground is approximately 50 feet and underground levels extend 30 feet below the surface. Two small rooms extend from the building's southern wall (see INL/EXT-06-11909 for further information).

Cultural Materials collected?

Yes

No $\mathrm{X}$

If yes, describe:

General Comments: The building's interior and exterior were inspected using the "EBR-I Preservation Plan" (INL/EXT-06-11909) as the basis for determining if direct or further cumulative impacts have occurred. No impacts have occurred that would affect EBR I's National Historic Landmark status.

Recommendations: $\quad$ Correct display technical problems. Install a water drainage system.

Attach additional documentation, as warranted (photos, profiles, etc.) $\quad$ Yes $\square$ No $\mathrm{X}$ If yes, describe:

Initials: JBB

Date: May 10, 2007 
Appendix A: Projects 


\begin{abstract}
Monitor Number: Monitor Name(s): Monitor Date:
\end{abstract}

Site Name/Number: $\quad$ National Security Large Scale Explosive Test Range Road Improvements Reason for monitoring: $\quad$ Surveillance of road grading to avoid impacts to known archaeological sites

\begin{tabular}{l|l|l|l|l|l|}
\hline Findings: & Type 1 & $\mathrm{X}$ & Type 2 & Type 3 & Type 4 \\
\hline
\end{tabular}

Impact Agent(s): $\quad$ Vehicle traffic, road grading and leveling, equipment turnaround

Significance of Impact: $\quad$ No grading was conducted within the boundaries of identified archaeological sites, so no impacts occurred.

Did disturbance or impact extend into undisturbed areas? $\quad$ Yes $\quad X \quad$ No

If yes, describe: Based on visual examination, road T-25 has been graded in the past, possibly during fire-fighting efforts or powerline maintenance

$\begin{array}{llll}\text { Work Halted? } & \text { Yes } \square \text { No } & \mathrm{X}\end{array}$

If yes, describe: $\mathrm{N} / \mathrm{A}$

Notifications: $\quad$ None

Primary contact(s): N/A

Date contacted: N/A

Contact Method: | E-mail

Cultural Materials observed? Yes $\mathrm{X}$ No $\square$

If yes, describe: Prehistoric lithic scatters are numerous along the powerline road (T-25) between the Materials and Fuels Complex (MFC) facility and the new National Security Test Range. They include: 10-BM-123, 10-BM-124, BEA-2006-20-7, 10-JF-77, 10-JF-78, 10-JF-80, 10-JF-83, 10-JF-84, and 10-JF-85.

Cultural Materials collected? Yes $\square$ No $\mathrm{X}$

If yes, describe: N/A

General Comments: No impacts to archaeological sites during road improvements. However, it is now very obvious where these sensitive resources are located. Gravel should be scattered in road along its entire length to camouflage their locations and help prevent unauthorized visitation and artifact collection. Additional monitoring should be conducted when gravel is added.

Recommendations: $\quad$ Conduct additional monitoring when road is graveled. Remind Test Range personnel of cultural resource training requirements. Obtain project funding for these efforts.

Attach additional documentation, as warranted (photos, profiles, etc.) $\quad$ Yes $X$ If yes, describe: photographs

Initials: HKG

Date: May 14, 2007 


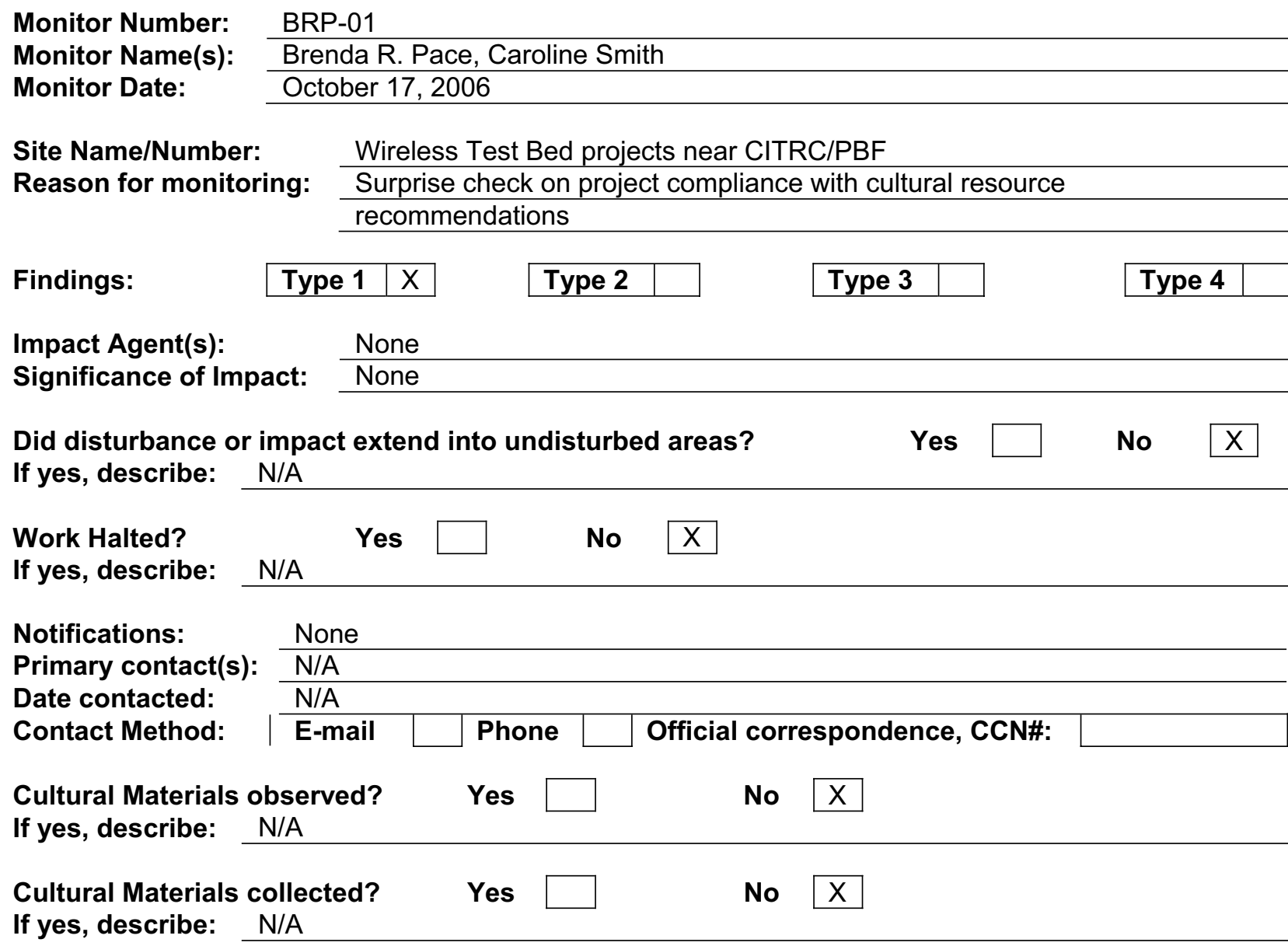

General Comments: Project is in compliance with cultural resource recommendations for installation of new cell tower and the new Drive-By Test Facility, both adjacent to Filmore Blvd.

Recommendations: $\quad$ Continue sporadic monitoring of activities in and around the CITRC/PBF area.

Attach additional documentation, as warranted (photos, profiles, etc.) $\quad$ Yes $\square$ No $\quad X$ If yes, describe:

Initials: $\quad B R P$

Date: October 17, 2006 


\begin{abstract}
Monitor Number: Monitor Name(s): Monitor Date:
\end{abstract}

BRP-03

Brenda R. Pace, Hollie Gilbert, Julie Braun March 22 - July 31,2007

Site Name/Number:

Geophysical Surveys in and around the Naval Ordnance Disposal Area

Reason for monitoring: $\quad$ Magnetometer surveys for unexploded ordnance (UXO) are utilizing a 6-Wheeler and a lightweight cart offroad to identify buried UXO and flag it for

future remediation. These project activities are being monitored to determine if the offroad activity results in impacts to known historic and prehistoric archaeological sites.

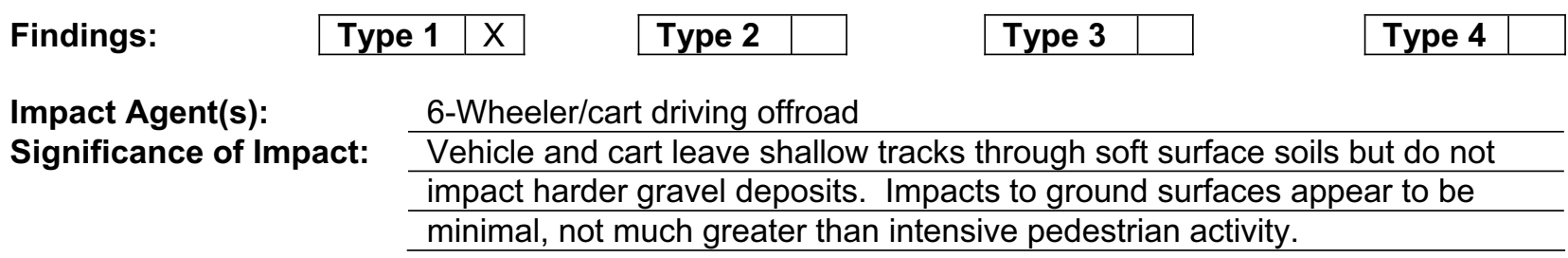

Did disturbance or impact extend into undisturbed areas?

Yes $\mathrm{X}$ No

If yes, describe: At the present time, 6 -Wheeler/cart surveys are restricted to areas previously surveyed for archaeological resources to assess impact and suitability for limited future deployment in unsurveyed areas. These areas are largely undisturbed.

Work Halted?

If yes, describe:
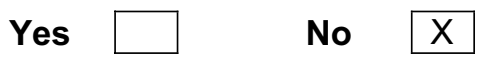

Notifications:

Primary contact(s):

Date contacted:

Contact Method:

N/A
$\frac{\text { None }}{\text { N/A }}$
$\frac{N}{\text { E-mail }}$
Phone Official correspondence, CCN\#:

\section{$\begin{array}{llll}\text { Cultural Materials observed? } & \text { Yes } X \text { No }\end{array}$}

If yes, describe: 6-Wheeler/cart survey passed through the boundaries of two known archaeological sites with no appreciable negative impacts (10-BT-1974 and LMIT-99-08-12)
Cultural Materials collected?
Yes
No $X$

If yes, describe: N/A

General Comments: $\quad$ On the floodplain deposits around NODA, offroad use of the 6-Wheeler and cart does not appear to adversely impact historic or prehistoric archaeological sites.

Faint tracks are visible through softer soils, but not on flood gravels. No surface artifacts were displaced or broken. Impacts are comparable to intensive foot traffic.

Recommendations: $\quad$ Continue monitoring offroad surveys in the vicinity of NODA. Carefully evaluate \begin{tabular}{l}
\hline any proposals to expand offroad surveys to other settings and soils as impacts \\
\hline may be higher where soils are sandier and less consolidated. Complete \\
\hline intensive archaeological surveys in advance of any proposed cleanup or \\
\hline remediation resulting from these surveys. Directly monitor any proposed \\
\hline removal inside the boundaries of known cultural resources.
\end{tabular}

Attach additional documentation, as warranted (photos, profiles, etc.)

Yes $\mathrm{X}$ No If yes, describe: photographs 
Idaho National Laboratory Cultural Resource Management Office Field Monitoring Form

Initials: $\quad B R P$

BRP

BRP

BRP

BRP
Date: $\quad$ March 22, 2007

April 6, 18, 19, 2007

May 2, 9, 21, 22, 29, 31, 2007

June $5,6,10,2007$

July $23,25,26,31,2007$ 
Idaho National Laboratory Cultural Resource Management Office

Field Monitoring Form

\begin{abstract}
Monitor Number: Monitor Name(s): Monitor Date:
\end{abstract}

BRP-07

Brenda R. Pace

August 16, 2007

Site Name/Number:

National Security Large Scale Explosive Test Range

Reason for monitoring: $\quad$ Check on project compliance with cultural resource recommendations

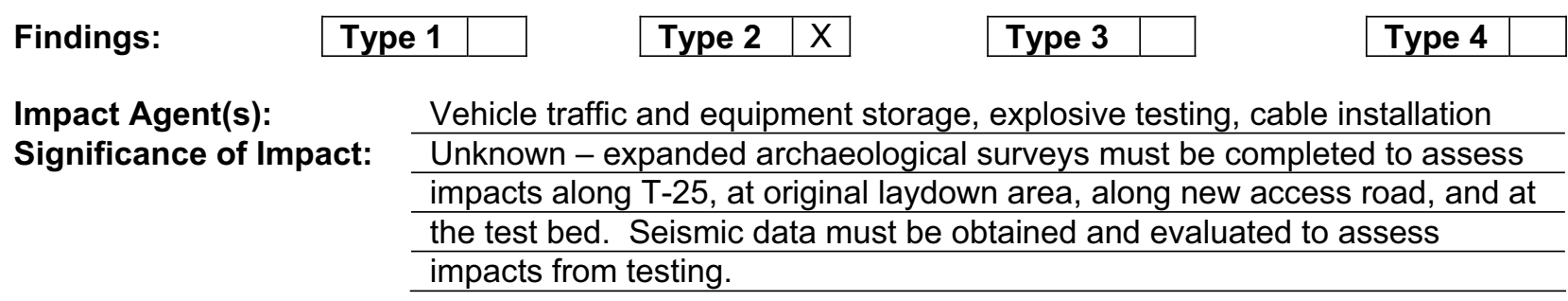

\begin{tabular}{ll|l|l|} 
Did disturbance or impact extend into undisturbed areas? & Yes & $X \quad$ No
\end{tabular}

If yes, describe: $\quad$ Original survey of project laydown area extends only to the south of the new access road. Project activities are now occurring to the north of the laydown area into unsurveyed lands. Project activities are extending beyond the 450' radius test bed and out to the widest limits of cultural resource survey coverage. Numerous vehicle turnarounds have been established along T-25, some inside the boundaries of known archaeological sites. Cables are laying on the surface of the ground outside the surveyed area along the new access road.

Work Halted? If yes, describe:
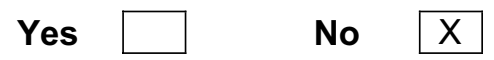

Notifications:

Primary contact(s):

Date contacted:

Contact Method:

N/A

No $\mathrm{X}$

\section{Cultural Materials observed? Yes $\square$ No $X$}

If yes, describe: Project activities are extending into unsurveyed areas and may be impacting cultural materials.

Cultural Materials collected? Yes $\square$ No $\quad$ No
If yes, describe: N/A

General Comments: Project is out of compliance with cultural resource recommendations as activities are extending into unsurveyed areas. Project has also failed to provide seismic monitoring data for 10-JF-88 from initial large tests. Support for ongoing cultural resource monitoring has also not been provided. Test Range personnel have not been trained in archaeological awareness and protection.

Recommendations: $\quad$ Consult directly with Environmental Compliance for assistance. Complete survey to north of original laydown area if project plans to continue storing equipment there. Install fence around all laydown areas and test bed, including any necessary fire protection zones. Expand survey along new access road for cable installation. Formally request seismic data collected from initial large test and clarify location and frequency of future seismic monitoring.

Remind Test Range personnel of cultural resource training requirements. Continue monitoring project compliance with all cultural resource recommendations as provided in the EA and EC. Obtain project funding for these efforts. 
Idaho National Laboratory Cultural Resource Management Office Field Monitoring Form

Attach additional documentation, as warranted (photos, profiles, etc.)

Yes

No $\mathrm{X}$ If yes, describe:

Initials: $\quad B R P$

Date: August 16, 2007 
Monitor Number:

BRP-11

Monitor Name(s):

Brenda R. Pace, Wendy Savkranz

Monitor Date:

August 6, 2007

Site Name/Number:

CWI Concrete Crusher near INTEC

Reason for monitoring: $\quad$ Project surveillance to confirm compliance with cultural resource recommendations.

Findings:

\begin{tabular}{|l|l|}
\hline Type 1 & $\mathrm{X}$ \\
\hline
\end{tabular}

Type 2

\begin{tabular}{|l|l|}
\hline Type 3 & \\
\hline
\end{tabular}

Type 4

Impact Agent(s): None

Significance of Impact: None

Did disturbance or impact extend into undisturbed areas?

If yes, describe: None

Work Halted?

If yes, describe:

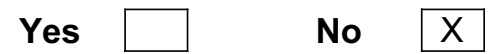

Notifications:

None

Primary contact(s): N/A

Date contacted: N/A

Contact Method: $\quad$ E-mail $\quad \square$ Phone $\square$ Official correspondence, CCN\#:

$\begin{array}{llll}\text { Cultural Materials observed? Yes } & \end{array} \quad$ No $\quad X$

If yes, describe: N/A

$\begin{array}{llll}\text { Cultural Materials collected? No } & \text { Nos } & \mathrm{X}\end{array}$

If yes, describe: $\mathrm{N} / \mathrm{A}$

General Comments: $\quad$ Project is in compliance with cultural resource recommendations and no adverse impacts have occurred or are anticipated. BEA Facilities and Site Services personnel provided incorrect information on cultural resource concerns to $\mathrm{CWI}$ and project.

Recommendations: $\quad$ Continue monitoring at this location given plans for intensive activities in the area. Repair fence and install signs. Discuss protocol for cultural resource information transmittal with BEA Facilities and Site Services and CWI to clarify that only the INL CRM Office can provide reliable information and recommendations.

Attach additional documentation, as warranted (photos, profiles, etc.)

Yes No $\mathrm{X}$ If yes, describe:

Initials: $\quad B R P$

Date: August 6, 2007 


\begin{abstract}
Monitor Number: Monitor Name(s): Monitor Date:
\end{abstract}

BRP-12

Brenda R. Pace

October 17, 2006 - September 6, 2007

Site Name/Number: Reason for monitoring:

Big Lost River Trenches

Project compliance with Memorandum of Agreement and consultation with the Shoshone-Bannock Tribes

Findings:

\begin{tabular}{|l|l|}
\hline Type 1 & $\mathrm{X}$ \\
\hline
\end{tabular}

Type 2

Type 3

Type 4

Impact Agent(s):

Significance of Impact: $\quad$ No impacts beyond original disturbed area

Did disturbance or impact extend into undisturbed areas?

Yes $\square$ No $\mathrm{X}$

If yes, describe: Backfilling operations carefully designed to prevent disturbance outside the original area of potential effect.

Work Halted?

If yes, describe:

Yes

No

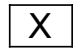

Notifications: Shoshone-Bannock Tribes

Primary contact(s): Caroline Smith

Date contacted: $\quad$ Multiple communications

\begin{tabular}{l|l|l|l|l|l|l|l} 
Contact Method: & E-mail & $\mathrm{X}$ & Phone & $\mathrm{X}$ & Official correspondence, CCN\#: & $\mathrm{DOE}-\mathrm{ID}$
\end{tabular}

Cultural Materials observed? Yes $X$ No

If yes, describe: Trenches were originally placed inside the boundaries of prehistoric lithic scatters as well as the historic Powell Stage Station. Artifacts and cultural features occur in all areas and were observed during the backfilling operations in undisturbed areas around the trenches. See forms for 10-BT-2194, 10-BT-2189, 10-BT-2193, and 10-BT-2192.

Cultural Materials collected? Yes $\square$ No $\mathrm{X}$ If yes, describe: $\mathrm{N} / \mathrm{A}$

General Comments: Backfilling activities began on August 28 and finished on September 6, 2007. Heritage Tribal Office monitors were present each day. Project personnel were cooperative and concerned about cultural resource protection, minimizing impact as much as possible. No new impacts occurred and no new artifacts were observed in the backdirt.

Recommendations: $\quad$ Monitor revegetation efforts in October.

Attach additional documentation, as warranted (photos, profiles, etc.) $\quad$ Yes $X$ No If yes, describe: photographs

Initials: $\quad B R P$

$$
\text { BRP }
$$

Date: August $28-30,2007$

September $4-6,2007$ 
Monitor Number:

Monitor Name(s):

Monitor Date:
BRP-18

Brenda R. Pace, Caroline Smith, Hollie Gilbert

Multiple dates

Site Name/Number:

Critical Infrastructure Test Range Complex (CITRC, formerly Power Burst Facility)

Reason for monitoring: $\quad$ Routine monitoring of ground disturbing activities within the CITRC/PBF area particularly in the vicinity of PER-632 and the Waste Experimental Reduction Facility (WERF) where human remains have been discovered in secondary (10-BT-1991) and original (10-BT-2046) contexts and as required by LWP8000 and MCP-3480.

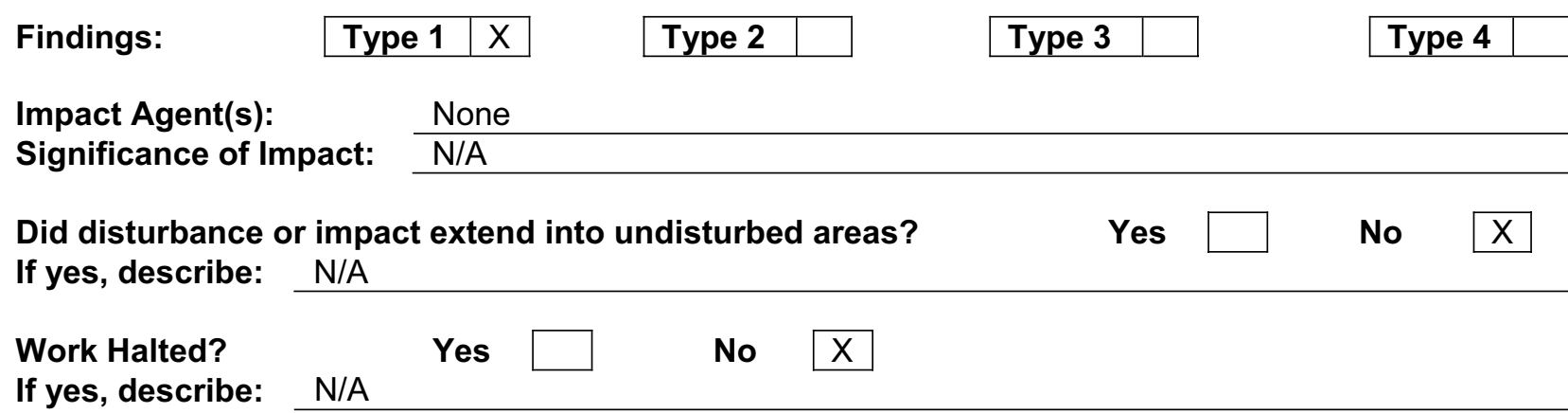

Notifications: $\quad$ None required under Type 1 finding

Primary contact(s): N/A

Date contacted: N/A

Contact Method: $\quad$ E-mail $\quad \square$ Phone $\square$ Official correspondence, CCN\#:

$\begin{array}{llll}\text { Cultural Materials observed? Nes } \square \text { No } & \end{array}$

If yes, describe: N/A

Cultural Materials collected? Yes $\square$ No $\mathrm{X}$

If yes, describe: N/A

General Comments: No artifacts or human remains observed in project excavations (tank removal near PER-632, mowing around WERF, parking lot grading near PER-620).

Recommendations: $\quad$ Continue routine monitoring of excavation projects in this sensitive area per the requirements of LWP-8000, MCP-3480, and the wishes of the ShoshoneBannock Tribes.

Attach additional documentation, as warranted (photos, profiles, etc.) $\quad$ Yes $\square$ No $\quad \mathrm{X}$ If yes, describe:

Initials: $\quad B R P$

\begin{tabular}{l}
\hline BRP \\
\hline BRP
\end{tabular}

Date: October 17, 2006

July 23, 2007

August 16, 2007 
